\title{
A New Synthesized Schiff Base as Corrosion Inhibitor for Mild Steel in a HCl Medium: Experimental, Density Functional Theory and Molecular Dynamics Simulation Studies
}

\author{
Ilhem Kaabi, ${ }^{1, *}$, Tahar Douadi ${ }^{1}$, Djamel Daoud ${ }^{1,2}$, \\ Samra Amamra ${ }^{3}$ and Salah Chafaa ${ }^{1}$ \\ ${ }^{1}$ Laboratory of Electrochemistry of Molecular and Complex Materials (LEMMC), \\ Department of Process Engineering, Faculty of Technology, \\ Ferhat ABBAS University of Setif-1, 19000 Setif, Algeria \\ ${ }^{2}$ Unity of Applied Research in Renewable Energies, URAER, Renewable Energy \\ Development Center, URAER, CDER, 47133 Ghardaïa, Algeria \\ ${ }^{3}$ Applied Biochemistry Laboratory, Faculty of Nature and Life Sciences, \\ Ferhat ABBAS University of Setif-1, 19000 Setif, Algeria \\ *Corresponding author: kaabi_ilh@yahoo.fr
}

Received 10/12/2018; accepted 15/02/2021

https://doi.org/10.4152/pea.2021390504

\begin{abstract}
A new inhibitor Schiff base ether ligand, $\mathrm{L}^{1}$, di[(4-phenylamino)2,4-dihydroxy salicylaldehyde], was synthesized and characterized using mass spectra, elemental analysis, IR spectra, UV-Vis spectra, ${ }^{1} \mathrm{H}$ NMR spectroscopy and thermal analysis. Electrochemical properties were investigated using cyclic Voltammetry (CV). The corrosion inhibition effect of the new prepared Schiff base was examined on mild steel (X48) in a $1 \mathrm{M} \mathrm{HCl}$ solution, by using gravimetric and electrochemical measurements. The potentiodynamic polarization results showed that the investigated Schiff base acted as a mixed kind inhibitor (cathodic/anodic), with some cathodic predominance. The adsorption procedure on X48 surface obeyed Langmuir isotherm. The associated adsorption activation factors and thermodynamic parameters were evaluated and interpreted. The inhibitor layer formed on the metal surface was characterized by AFM and SEM. The solid-state molecular geometry has been studied with the theoretical data obtained by density functional theory (DFT). Furthermore, the interaction between the inhibitor and $\mathrm{Fe}\left(\begin{array}{lll}1 & 1 & 0\end{array}\right)$ surface was achieved by molecular dynamics simulations.
\end{abstract}

Keywords: Schiff base, electrochemistry, corrosion inhibition, AFM and SEM.

\section{Introduction}

Organic molecules containing imine groups have been of interest to inorganic chemists. These categories of molecules were found to be good ligands and to have utility in a broad range of applications [1-5]. Undoubtedly, the Schiff base ligands receiving the most attention have been those classified as Salen type ligands. Schiff bases constitute a potential class of corrosion inhibitors and, 
besides this, they have various important proprieties and extensive usages in medicine [6], pharmaceutical fields [7] and material science [8].

The application of organic corrosion inhibitors is a promising key alternative. Various types of organic structures have been designated to act as corrosion inhibitors [9-11]. The existing statistics indicate that the majority of organic inhibitors proceed by adsorption onto the metal surface. Most of the effective inhibitors utilized in industry are organic compounds, which mainly contain oxygen, sulfur, nitrogen atoms and multiple bonds. Those compounds inhibitory effect is attributed to their interactions with the metal surface, by adsorption. It has been detected that adsorption mainly depends on some physicochemical inhibitors characteristics, for example: electron density of the contributor atom, $\pi$-orbital character and the molecule electronic structure [12]. The functional groups contained in the organic structures act as reaction sites for the adsorption process [2]. The $-\mathrm{C}=\mathrm{N}$ - group presence in Schiff bases enhances the corrosion inhibitor adsorption capacity and effectiveness [13]. These inhibitors are frequently adsorbed onto the mild steel surface, by the creation of a covalent bond (chemical adsorption), or by the electrostatic interaction between the metal and the inhibitor (physical adsorption). In addition, Schiff bases have shown a variety of biological actions through the azomethine bond that is accountable for several antibacterial, antifungal, herbicidal, clinical and antioxidant activities [14-17].

The objective of this work is the synthesis and characterization of a novel Schiff base ligand $\left(\mathrm{L}^{1}\right) ; \mathrm{L}^{1}=\mathrm{di}$ [(4-phenylamino)-2,4-dihydroxy-salicylaldehyde)] ether, which involves $\mathrm{N}_{2} \mathrm{O}_{2}$ donor centers. The corrosion inhibition of this ligand $\left(\mathrm{L}^{1}\right)$, on $\mathrm{X} 48$ mild steel in a $1 \mathrm{M} \mathrm{HCl}$ medium, was examined by weight loss, polarization method, electrochemical impedance measurements, quantum chemistry calculations and molecular dynamics simulations.

\section{Experimental procedures \\ Mild steel composition}

The mild steel (X48) containing (wt. \%) of $0.09 \% \mathrm{C}, 0.058 \% \mathrm{Si}, 0.91 \% \mathrm{Mn}$, $0.014 \% \mathrm{P}, 0.002 \% \mathrm{~S}, 0.048 \% \mathrm{~V}, 0.001 \% \mathrm{Ti}, 0.056 \% \mathrm{Nb}, 0.044 \% \mathrm{Al}$ and balance Fe was submitted to electrochemical examination.

\section{Inhibitor}

4,4'-diaminodiphenyl ether and 2,4-dihydroxy salicylaldehyde were purchased from Sigma-Aldrich, France. The inhibitor, $\mathrm{L}^{1}$ ether, di[(4-henylamino)2,4dihydroxy salicylaldehyde], was synthesized in our laboratory.

\section{Solution}

The $1 \mathrm{M} \mathrm{HCl}$ acidic medium was prepared by dilution of $\mathrm{AR}$ grade $37 \% \mathrm{HCl}$ in bidistilled water. The $\mathrm{L}^{1}$ stock solutions were properly diluted, to obtain the various concentrations $\left(1.0 \times 10^{-6}, 1.0 \times 10^{-5}, 2.5 \times 10^{-5}, 5.0 \times 10^{-5}\right.$ and $\left.7.5 \times 10^{-5} \mathrm{M}\right)$, and they were utilized in the corrosion inhibition study. 


\section{Measurements}

The melting points were measured by a Kofler bank, and they have not been corrected. The IR spectra were recorded on a Perkin-Elmer 1000 series FT-IR spectrophotometer, using $\mathrm{KBr}$ disks. The UV-vis. spectra were obtained by DMF, with a UNICAM UV-300 spectrophotometer, with $1 \mathrm{~cm}$ quartz cuvettes. The ${ }^{1} \mathrm{H}$ NMR spectra were recorded on a Jeol GSX WB spectrometer, at $270 \mathrm{MHz}$, in DMSO-d $_{6}$ (dimethyl sulfoxide); the chemical shifts are given in ppm, using TMS as an internal reference. Mass spectra were measured in a positive mode, and in the range from $\mathrm{m} / \mathrm{z}=100$ to 500 . Cyclic Voltammetry was recorded on a Voltalab32 (DEA 332 type) Radiometer. The working electrode was a $1 \mathrm{~mm}$ diameter mild steel disk, the auxiliary electrode was a Pt wire and a saturated calomel electrode was employed as the reference electrode. Measurements were performed at $25 \pm$ $0.2^{\circ} \mathrm{C}$. DMSO was utilized as a solvent, and the ionic strength was maintained at $0.1 \mathrm{~mol} \mathrm{~L}^{-1}$, with TBAP (Tetrabutylammonium perchlorate), as supporting electrolyte. The species concentrations were in the $5 \times 10^{-3} \mathrm{~mol} \mathrm{~L}^{-1}$ range. The sweep speed was $100 \mathrm{mV} \mathrm{s}^{-1}$, unless otherwise specified.

\section{$L^{1}$ ligand synthesis}

The $\mathrm{L}^{1}$ synthetic route given by the literature [18-24] is outlined in Scheme 1. The di [(4-phenylamino) 2,4-dihydroxy salicylaldehyde)] $\mathrm{L}^{1}$ ether ligand was obtained by the contact of $1 \mathrm{mmol}(0.2 \mathrm{~g}) 4,4^{\prime}$-diaminodiphenyl ether, in $15 \mathrm{~mL}$ absolute ethanol, with $2 \mathrm{mmol} 2,4-$ dihydroxy salicylaldehyde $(0.26 \mathrm{~g})$, in $10 \mathrm{~mL}$ ethanol. The mixture was refluxed for $3 \mathrm{~h}$, followed by cooling to ambient temperature. The yellow product was filtered, washed twice with Et-OH $(2 \mathrm{~mL} \times 3)$, followed by diethyl ether $(5 \mathrm{~mL} \times 2)$, recrystallized from THF and Ethanol, and then dried in vacuum. Its yield was almost $88.5 \%$.

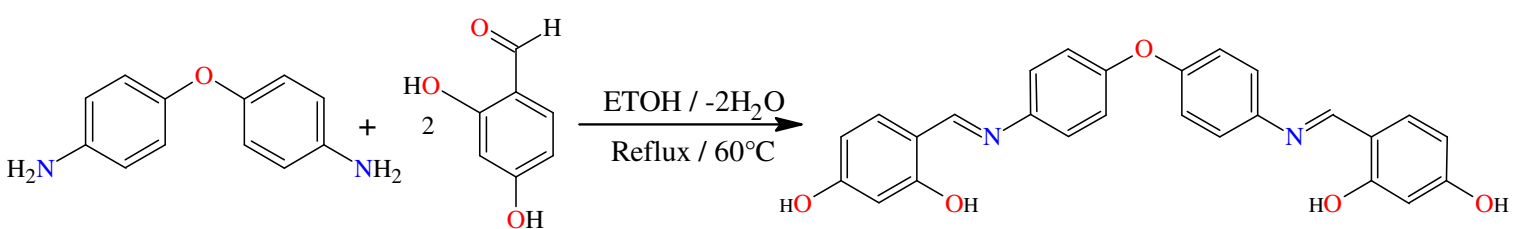

Scheme 1. Synthetic route to the $\mathrm{L}^{1}$ ligand.

\section{Experimental techniques}

Gravimetric experiments

Weight loss measurements are the simplest method to find the corrosion rate and the inhibitory effect. In this study, X48 specimens were immersed in $80 \mathrm{~mL}$ of a 1 $\mathrm{M} \mathrm{HCl} \mathrm{medium,} \mathrm{in} \mathrm{the} \mathrm{absence} \mathrm{and} \mathrm{presence} \mathrm{of} \mathrm{different} \mathrm{tested} \mathrm{Schiff} \mathrm{base}$ concentrations, for an exposure period of $24 \mathrm{~h}$. The X48 mild steel specimens, utilized by the gravimetric method, were cut in order to get cylindrical surfaces with an exposed area of $33.912 \mathrm{~cm}^{2}$, successively abraded with several grades of emery papers, washed thoroughly with doubled distilled water, degreased with acetone and, finally, dried. The specimens weight, prior and after submersion, was 
measured using a Mettler balance. Triplicate experiments were performed for each inhibitor concentration, for reproducibility. The inhibitor concentration effect on inhibition efficiency, $\operatorname{IE}_{\mathrm{w}}(\%)$, was studied, to obtain the specimen weight loss, by the gravimetric method, with different concentrations $\left(1.0 \times 10^{-6}, 1.0 \times 10^{-5}, 2.5 \times 10^{-}\right.$ 5 , $5.0 \times 10^{-5}$ and $\left.7.5 \times 10^{-5} \mathrm{M}\right)$. The corrosion rate, $\mathrm{W}$, was calculated by using equation (1).

$$
W\left(\mathrm{mg} \mathrm{cm}^{-2} \mathrm{~h}^{-1}\right)=\frac{m_{1}-m_{2}}{S \times t}
$$

where $\mathrm{m}_{1}(\mathrm{mg})$ is the uncorroded specimen mass, $\mathrm{m}_{2}(\mathrm{mg})$ is the corroded specimen weight, $\mathrm{S}\left(\mathrm{cm}^{2}\right)$ is the specimen total area, $\mathrm{t}\left(\mathrm{h}^{-1}\right)$ is the corrosion time, and $\mathrm{W}\left(\mathrm{mg} \mathrm{cm} \mathrm{cm}^{-2} \mathrm{~h}^{-1}\right)$ is the corrosion rate. The $\mathrm{IE}_{\mathrm{w}}(\%)$ was determined by employing equation (2) [25].

$$
I E_{\mathrm{w}}(\%)=\frac{w_{0}-w_{\mathrm{inh}}}{w_{0}} \times 100
$$

where $\mathrm{w}_{0}\left(\mathrm{mg} \mathrm{cm}^{-2} \mathrm{~h}^{-1}\right)$ is the corrosion rate without inhibitor and $\mathrm{w}_{\mathrm{inh}}\left(\mathrm{mg} \mathrm{cm}^{-2} \mathrm{~h}^{-}\right.$ $\left.{ }^{1}\right)$ is the corrosion rate with the inhibitor.

\section{Electrochemical proceedings}

The electrochemical measurements were carried out in a three-compartment Pyrex cell, with a separate compartment for the saturated calomel (SCE) reference electrode that was connected to the main compartment via a Lugging capillary. A platinum foil was used as the counter electrode $\left(2 \mathrm{~cm}^{2}\right.$ area $)$. The employed working electrode was prepared using X48 mild steel, in the form of a cylindrical rod, embedded in epoxy resin, leaving an open surface area of $0.28 \mathrm{~cm}^{2}$. The working electrode was mechanically smoothed by emery paper (220 and 4000 grades), washed with double distilled water, and then placed in the test solution. The electrochemical data were obtained after $30 \mathrm{~min}$. of immersion in an experimental solution, ensuring a reliable corrosion potential and an equilibrated system.

The polarization measurements were performed at a scan rate of $0.5 \mathrm{mV} \mathrm{s}^{-1}$, from 800 to $-300 \mathrm{mV}$ potential ranges. First, the aqueous electrolyte medium $(1 \mathrm{M} \mathrm{HCl})$ was prepared from $37 \% \mathrm{HCl}$ analytical grade (Merck) and bidistilled water. The measurements were performed in $1 \mathrm{M} \mathrm{HCl}$ with and without the examined Schiff base compound, in the concentration range of $10^{-6} \mathrm{M}$ to $7.5 \times 10^{-5} \mathrm{M}$. Then, all electrochemical calculations were carried out at ambient temperature, utilizing a PGZ-301 Voltalab-40 potentiostat/galvanostat model. The data were analyzed using a Pentium-IV computer with Volta Master IV program. The linear Tafel segments of anodic and cathodic curves were extrapolated to corrosion potential $\left(\mathrm{E}_{\text {corr }}\right)$, to obtain corrosion current densities ( $\left.\mathrm{i}_{\text {corr }}\right)$. The $\operatorname{IE}_{\mathrm{p}}(\%)$ (inhibition efficiency percentage), at different inhibitor concentrations, was calculated using equation (3).

$$
I E_{\mathrm{p}}(\%)=\left(\frac{i_{\mathrm{corr}}^{0}-i_{\mathrm{corr}}}{i_{\mathrm{corr}}^{0}}\right) \times 100
$$

where $i_{\text {corr }}^{\circ}\left(\mathrm{mA} \mathrm{cm}^{-2}\right)$ and $\mathrm{i}_{\text {corr }}\left(\mathrm{mA} \mathrm{cm}^{-2}\right)$ represent the corrosion current density vapors without and with inhibitor, respectively. 
The electrochemical impedance spectroscopy (EIS) was carried out at OCP, in the frequency range from $100 \mathrm{KHz}$ to $10 \mathrm{mHz}$, with a signal amplitude perturbation of $5 \mathrm{mV}$. The inhibition efficiency resistance, $\operatorname{IE}_{R}(\%)$, was estimated by equation (4).

$$
I E_{\mathrm{R}}(\%)=\left(\frac{R_{c t}-R_{c t_{0}}}{R_{c t}}\right) \times 100
$$

where $R_{\mathrm{ct}_{0}}\left(\Omega \mathrm{cm}^{2}\right)$ and $\mathrm{R}_{\mathrm{ct}}\left(\Omega \mathrm{cm}^{2}\right)$ are charge transfer resistance for X48 mild steel, in the inhibitor absence and presence, respectively. Nyquist and bode plots were drawn from these experiments.

\section{Surface morphology (AFM and SEM)}

The pictures of the oxidized area, before and after the inhibitor addition, were recorded by atomic force microscopy (AFM) and scanning electron microscopy (SEM). X 48 mild steel samples, with the dimensions of $2 \times 2 \times 0.4 \mathrm{~cm}$, were prepared. After immersion in a $1 \mathrm{M} \mathrm{HCl}$ solution, without and with the addition of $7.5 \times 10^{-5} \mathrm{M}$ of $\mathrm{L}^{1}$, at $25^{\circ} \mathrm{C}$, for $24 \mathrm{~h}$, the specimens were cleaned with distilled water, dried with a cold air blaster, and then examined by an MFP-3D AFM (Asylum Research, an Oxford Instruments company) and JEOL-JSM-7001F SEM (Japan).

\section{Theoretical study}

\section{Quantum chemical calculations}

The computational calculations of the studied Schiff base were carried out using the Gauss View Molecular Visualization program [26] and standard Gaussian 09 software package [27]. Geometry optimization was performed by density functional theory (DFT) level, with the non-local B3LYP hybrid density functional [28], at 6-31G (d, p) basis sets [29]. The quantum chemical indices have been taken into account: energy of the highest occupied molecular orbital (Eномо), energy of the lowest unoccupied molecular orbital ( $E_{\text {LUMO }}$ ), energy gap $\left(\Delta \mathrm{E}_{\mathrm{gap}}=\mathrm{E}_{\mathrm{HOMO}}-\mathrm{E}_{\mathrm{LUMO}}\right)$, dipole moment $(\mu)$ and Mulliken charge.

\section{Molecular dynamics simulation}

Molecular dynamics simulation (MDS) has appeared as a modern tool for studying the contact between the inhibitor molecule and the concerned metal surface [30]. The interaction between the investigated Schiff base and the iron surface was simulated via a Forcite module of Materials Studio 7.0 software developed by Accelrys Inc. [31]. Herein, the Fe (lll 110$)$ surface was carefully chosen as the adsorption substrate, due to its packed surface and better stabilization. The simulations were made in a simulation box $(24.82 \AA \times 24.82 \AA \times 20.13 \AA)$, with periodic boundary conditions. The box included a Fe slab, an acidic solution layer and a vacuum layer. The MD simulations were realized by the COMPASS force field, in an NVT ensemble, at $298 \mathrm{~K}$, commanded by an Andersen thermostat, with a time step of $1 \mathrm{fs}$ and dynamics time of $5 \mathrm{ps}$. The total simulation time was 5000 ps. Non-bonded interactions and van der Waals and electrostatic interactions were set using atom-based summation method and Ewald summation tool. The 
interaction energy between the inhibitor molecules and the Fe $\left(\begin{array}{lll}1 & 1 & 0\end{array}\right)$ surface was obtained using equation (5) [32].

$$
E_{\text {jint }}=E_{\text {total }}-\left(E_{\text {surf }}-E_{\text {Inh }}\right)
$$

where $\mathrm{E}_{\text {total }}\left(\mathrm{kcal} \mathrm{mol}^{-1}\right)$ is the simulation system total energy, $\mathrm{E}_{\text {surf }}\left(\mathrm{kcal} \mathrm{mol}^{-1}\right)$ is the iron surface energy and $\mathrm{E}_{\mathrm{inh}}\left(\mathrm{kcal} \mathrm{mol}^{-1}\right)$ is the free inhibitor molecule energy. The binding energy $\left(\mathrm{E}_{\mathrm{bin}}\right)$ is $\mathrm{E}_{\mathrm{int}}: \mathrm{E}_{\mathrm{bin}}=-\mathrm{E}_{\text {int }}$.

\section{Results and discussion}

\section{$L^{1}$ preparation and characterization}

\section{Preparation}

The ligand synthesis reaction is given in Scheme 1. It is the condensation between 4,4'-diaminodiphenyl ether and 2,4-dihydroxy salicylaldehyde, to give $\mathrm{L}^{1}$ ether, di [(4-phenylamino)2,4-dihydroxy salicylaldehyde].

The analytical and spectral data of the Schiff base ligand are summarized in Table 1 .

Table 1. Analytical and spectroscopic data for the $\mathrm{L}^{1}$ ligand.

\begin{tabular}{|c|c|c|c|c|c|c|c|c|c|c|}
\hline \multirow[t]{2}{*}{ Compound } & \multirow[t]{2}{*}{$\begin{array}{c}\text { Yield } \\
(\%)\end{array}$} & \multirow[t]{2}{*}{ Color } & \multirow[t]{2}{*}{$\begin{array}{l}\text { M.P } \\
\left({ }^{\circ} \mathbf{C}\right)\end{array}$} & \multicolumn{3}{|c|}{$\begin{array}{c}\text { Found Elemental } \\
\text { analysis } \\
\text { (Cal.) } \\
(\%)\end{array}$} & \multicolumn{3}{|c|}{$\begin{array}{c}\text { Infrared } \\
(\mathrm{KBr} \text { pellets }) \\
\left(\mathrm{cm}^{-1}\right)\end{array}$} & \multirow{2}{*}{\begin{tabular}{|c|}
$\begin{array}{c}\text { UV-vis DMF } \\
\text { solution }\end{array}$ \\
$\lambda_{\max }$ \\
$(\mathbf{n m})$
\end{tabular}} \\
\hline & & & & $\mathrm{C}$ & $\mathbf{H}$ & $\mathbf{N}$ & $\mathbf{v}(\mathrm{O}-\mathrm{H})$ & $v(C=N)$ & $v(C-O-C)$ & \\
\hline $\mathbf{L}^{\mathbf{1}}\left(\mathrm{C}_{26} \mathrm{H}_{20} \mathrm{~N}_{2} \mathrm{O}_{5}\right)$ & 88.5 & Yellow & 260 & $\begin{array}{l}72.08 \\
(70.90)\end{array}$ & $\begin{array}{c}5.39 \\
(4.58)\end{array}$ & $\begin{array}{c}7.02 \\
(6.36)\end{array}$ & 3230 & 1640 & 1260 & 286,354 \\
\hline
\end{tabular}

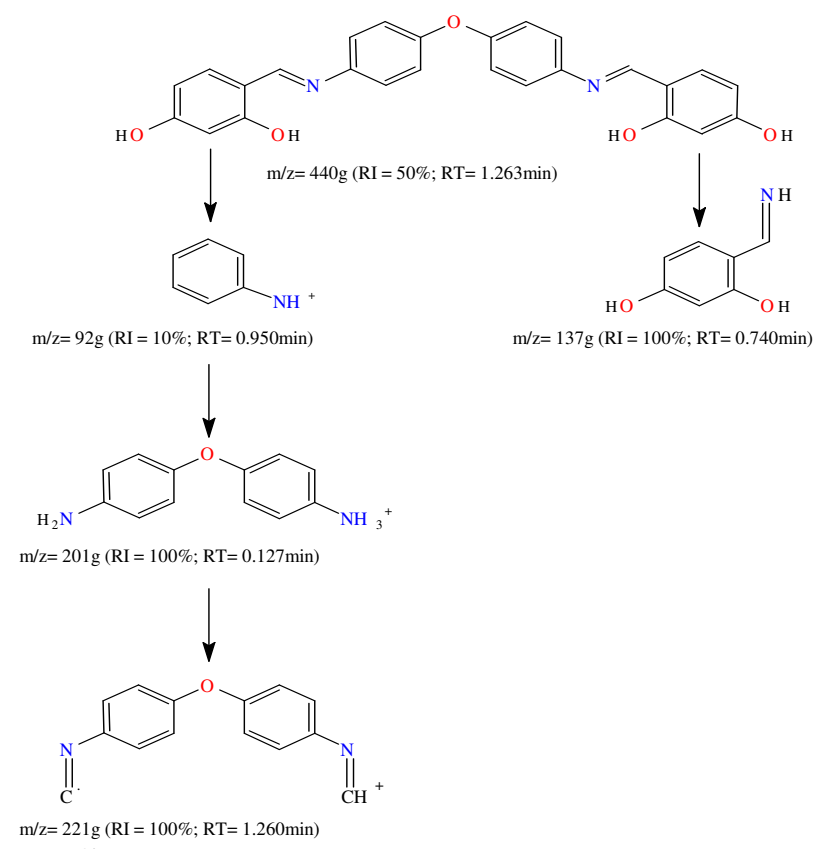

Scheme 2. L1 mass fragmentation pattern. 


\section{Characterization}

\section{Mass spectra}

The $\mathrm{L}^{1}$ ligand electron impact mass spectra confirm the probable formula, by showing a $\mathrm{m} / \mathrm{z}=440 \mathrm{~g}$ peak (Scheme 2), which corresponds to the macrocyclic moiety $\left(\mathrm{C}_{26} \mathrm{H}_{20} \mathrm{~N}_{2} \mathrm{O}_{5}\right)$.

\section{Infrared spectra}

The ligand infrared spectra were recorded in $\mathrm{KBr}$ pellets, from 4000 to $400 \mathrm{~cm}^{-1}$ (Table 1). The ligand azomethine groups vibration was observed at $1640 \mathrm{~cm}^{-1}$ [34, 35]. Additionally, the ligand peaks, observed at $1260 \mathrm{~cm}^{-1}$, have been assigned to the etheric $\mathrm{C}-\mathrm{O}-\mathrm{C}$ stretching.

\section{${ }^{1} \mathrm{H}$ NMR spectra}

$\mathrm{L}^{1}$ ligand ${ }^{1} \mathrm{H}$ NMR spectra, recorded in DMSO-d 6 (Table 1), showed: two signals at 13.5 and $10.25 \mathrm{ppm}(\mathrm{s} ; 2 \mathrm{H})$, assigned to $\mathrm{OH}$ phenolic; one signal at $8.8 \mathrm{ppm}(\mathrm{s}$; $2 \mathrm{H}$ ), assigned to $\mathrm{CH}=\mathrm{N}$ [36]; and four signals at 7-7.2 ppm, 7.4-7.6 ppm, 6.2-6.4 $\mathrm{ppm}$ and 6.4-6.6 ppm, in the form of multiplets, assigned to aromatic $\mathrm{CH}$ [37].

\section{Electronic spectra}

The ligand electronic spectra were recorded in the field (200-600 nm), in DMF, and the relevant data are presented in Table 1. The band observed at $286 \mathrm{~nm}$ is assigned with the $\pi-\pi^{*}$ transitions aromatic nucleus [38], and other band located at $354 \mathrm{~nm}$ is due to $\pi-\pi^{*}$ transitions $[39,40]$.

\section{Electrochemistry}

The $\mathrm{L}^{1}$ electrochemical behavior was investigated using cyclic Voltammetry (CV) technique, in a DMSO solution containing 0.1 M TBAP, on a platinum working electrode and a saturated calomel reference electrode. The data obtained in this work are listed in Table 2.

Table 2. Voltammetry results for the $\mathrm{L}^{1}$ ligand, at $25^{\circ} \mathrm{C}$, in DMSO, with an ionic strength of $0.1 \mathrm{~mol} \mathrm{~L}^{-1}$ (TBAP). Results in V/ECS: $\mathrm{E}_{\mathrm{pa}}$, anodic; $\mathrm{E}_{\mathrm{pc}}$, cathodic.

\begin{tabular}{|c|c|c|c|c|c|c|c|c|}
\hline Compound & $\mathrm{E}_{\mathrm{pa} 1}$ & $\mathrm{E}_{\mathrm{pa} 2}$ & $\mathrm{E}_{\mathrm{pc} 1}$ & $\mathrm{E}_{\mathrm{pa} 3}$ & $\mathrm{E}_{\mathrm{pa} 4}$ & $\mathrm{E}_{\mathrm{pc} 2}$ & $\mathrm{E}_{\mathrm{pc} 3}$ & $\mathrm{E}_{\mathrm{pc} 4}$ \\
\hline $\begin{array}{c}\mathrm{L}^{1}\left(\mathrm{C}_{26} \mathrm{H}_{20} \mathrm{~N}_{2} \mathrm{O}_{5}\right) \\
\text { 4-acetamidonaphthalic } \\
\text { anhydride }\end{array}$ & 0.46 & 0.87 & 0.38 & -0.50 & - & -0.75 & -1.30 & -1.6 \\
\hline
\end{tabular}

For the $\mathrm{L}^{1}$ ligand, a cyclic sweep, from the +0.25 to $1.0 \mathrm{~V} / \mathrm{SCE}$ range, shows one cathodic peak at $0.38 \mathrm{~V} / \mathrm{SCE}$ and two anodic peaks at +0.46 and $+0.87 \mathrm{~V} / \mathrm{SCE}$; the latter is due to the phenolic grouping oxidation (Fig. 1a) [41].

The cyclic voltammogram for the electro-reduction shows three cathodic peaks: the first, at $-1.65 \mathrm{~V} / \mathrm{SCE}$, is due to the molecule imino moiety reduction $[22,40$ $42]$; the second, at $-1.30 \mathrm{~V} / \mathrm{SCE}$; and the third is due to quasi-reversible reduction processes located at $-0.75 \mathrm{~V} / \mathrm{SCE}$, with the corresponding cathodic peak at -0.50 V/SCE (Fig. 1b). 


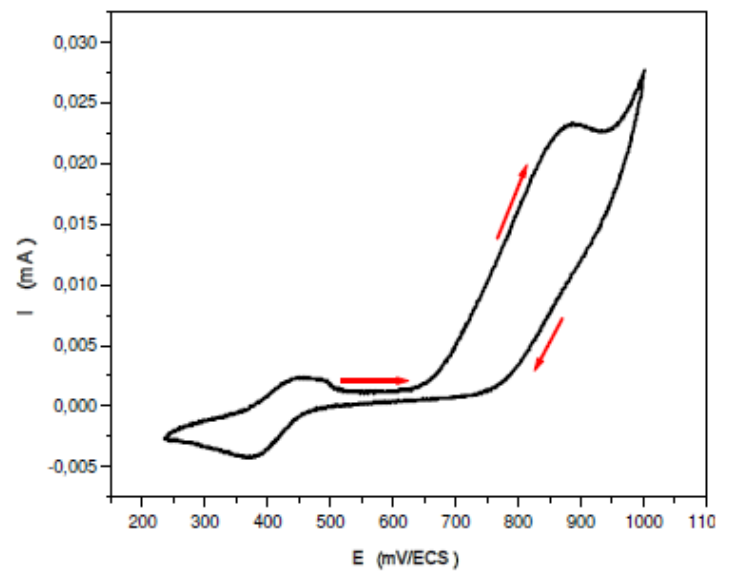

(a)

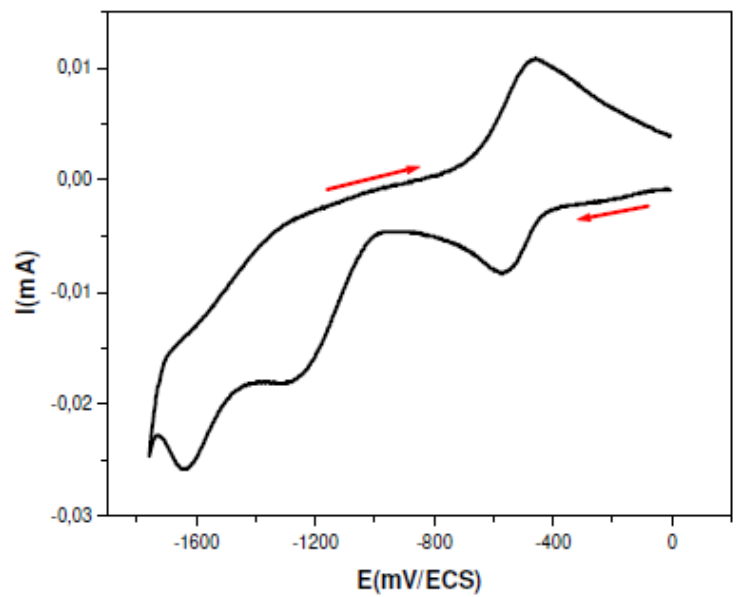

(b)

Figure 1. Cyclic Voltammogram of $\mathrm{L}^{1}$ ligand: $5 \times 10^{-3}$ mol L $\mathrm{L}^{-1}$ in $0.1 \mathrm{~mol} \mathrm{~L} \mathrm{~L}^{-1}$ DMSOTBAP. $v=100 \mathrm{mV} \mathrm{s}^{-1}$. ET: Pt. (a) $250 \mathrm{mV}$ to $1000 \mathrm{mV} / \mathrm{SCE}$, (b) 0 to $-1800 \mathrm{mV} / \mathrm{SCE}$.

\section{$L^{1}$ corrosion inhibition study}

Gravimetric experiments

The inhibitory effect of the examined $\mathrm{L}^{1}$ Schiff base, with different concentrations, was determined in a $1 \mathrm{M} \mathrm{HCl}$ medium, at $298 \mathrm{~K}$, for a $24 \mathrm{~h}$ immersion.

Corrosion rate, $\mathrm{W}$, and inhibition efficiency, $\mathrm{IE}_{\mathrm{w}}(\%)$, values were calculated using Equation (1) and (2), respectively. The results are presented in Table 3.

Table 3. Mild steel corrosion factors found from weight loss experiments in a $1 \mathrm{M} \mathrm{HCl}$ medium containing $\mathrm{L}^{1}$ with different concentrations, at $298 \mathrm{~K}$, after $24 \mathrm{~h}$ on plunge.

\begin{tabular}{|c|c|c|c|}
\hline $\begin{array}{l}C_{\text {inh }} \\
(\mathrm{M})\end{array}$ & $\begin{array}{l}\Delta m \\
(\mathrm{~g})\end{array}$ & $\begin{array}{c}W \\
\left(\mathrm{mg} \mathrm{cm}^{-2} \mathbf{h}^{-1}\right)\end{array}$ & $\begin{array}{l}E I_{\mathrm{w}} \\
(\%)\end{array}$ \\
\hline Blank & 1.1898 & $1.461 \pm 0.0142$ & - \\
\hline $1.0 \times 10^{-6}$ & 1.1510 & $1.414 \pm 0.0039$ & 3.210 \\
\hline $1.0 \times 10^{-5}$ & 0.9845 & $1.209 \pm 0.0051$ & 17.20 \\
\hline $2.5 \times 10^{-5}$ & 0.8634 & $1.060 \pm 0.0031$ & 27.44 \\
\hline $5.0 \times 10^{-5}$ & 0.1427 & $0.175 \pm 0.0019$ & 88.00 \\
\hline $7.5 \times 10^{-5}$ & 0.0928 & $0.114 \pm 0.0027$ & 92.19 \\
\hline
\end{tabular}

It is clear that $\mathrm{L}^{1}$ inhibition efficiency, $\mathrm{EI}_{\mathrm{w}}(\%)$, and its corrosion rate, $\mathrm{W}$, increase with higher inhibitor concentrations, exhibiting their maximum values $(92.19 \%$ and $0.114 \mathrm{mg} \mathrm{cm}^{-2} \mathrm{~h}^{-1}$, respectively) at the concentration of $7.5 \times 10^{-5} \mathrm{M}$. This phenomenon can be due to the formation of a layer adsorbed onto the metallic surface.

\section{Polarization experiments}

Potentiodynamic polarization branches for mild steel in a $1 \mathrm{M} \mathrm{HCl}$ solution, in L1 absence and presence, with various concentrations, after immersion for $30 \mathrm{~min}$, at 298 K, are shown in Fig. 2. 
Electrochemical settings, such as corrosion potential ( $\left.E_{\text {corr }}\right)$, corrosion current density ( $\left.i_{\text {corr }}\right)$, anodic and cathodic Tafel slopes $(\beta a$ and $\beta c)$ were calculated, and are shown in Table 4.

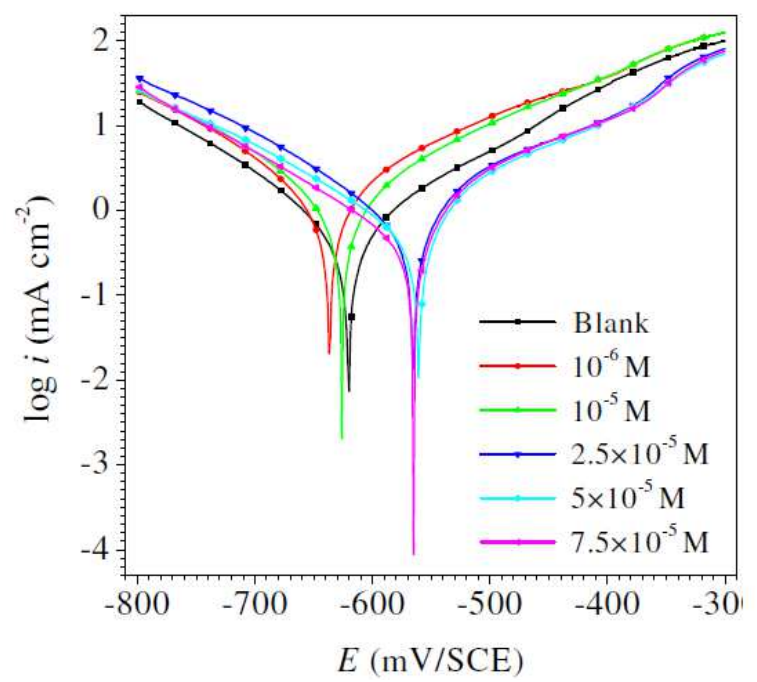

Figure 2. Mild steel electrode polarization plots obtained in a $1 \mathrm{M} \mathrm{HCl}$ solution containing different Schiff base compound concentrations, at $25^{\circ} \mathrm{C}$.

Table 4. Polarization data and corresponding inhibition efficiency for mild steel in $1 \mathrm{M}$ $\mathrm{HCl}$, with and without the examined Schiff base, with different concentrations, at $25^{\circ} \mathrm{C}$.

\begin{tabular}{|c|c|c|c|c|c|c|c|}
\hline $\begin{array}{l}C_{\text {inh }} \\
(\mathrm{M}) \\
\end{array}$ & $\begin{array}{c}-E_{\text {corr }} \\
(\mathrm{mV} / \mathrm{ECS})\end{array}$ & $\begin{array}{c}-\beta_{\mathrm{c}} \\
(\mathrm{mV} / \mathrm{dec})\end{array}$ & $\begin{array}{c}\beta_{\mathrm{a}} \\
\mathrm{mV} / \mathrm{dec})\end{array}$ & $\begin{array}{c}R_{\mathrm{p}} \\
\left(\Omega \mathrm{cm}^{2}\right)\end{array}$ & $\begin{array}{c}i_{\text {corr }} \\
\left(\mathrm{mA} \mathbf{c m}^{-2}\right)\end{array}$ & $\begin{array}{l}I E_{\mathrm{p}} \\
(\%)\end{array}$ & $\theta$ \\
\hline Blank & 554 & 127.8 & 160.8 & 17.04 & 1.672 & - & - \\
\hline $1.0 \times 10^{-6}$ & 636 & 114.0 & 118.2 & 18.94 & 1.200 & 28.14 & 0.28 \\
\hline $1.0 \times 10^{-5}$ & 626 & 106.4 & 110.4 & 21.38 & 0.980 & 41.31 & 0.41 \\
\hline $2.5 \times 10^{-5}$ & 565 & 104.4 & 71.6 & 30.16 & 0.500 & 70.05 & 0.70 \\
\hline $5.0 \times 10^{-5}$ & 560 & 115.6 & 65.7 & 35.19 & 0.410 & 75.44 & 0.75 \\
\hline $7.5 \times 10^{-5}$ & 565 & 91.0 & 49.8 & 39.41 & 0.270 & 83.83 & 0.83 \\
\hline
\end{tabular}

It is clear in Fig. 2 that the cathodic curves show a lower current density in $\mathrm{L}^{1}$ presence than that recorded in the $\mathrm{HCl}$ medium. $\mathrm{E}_{\text {corr }}$ (Table 4), in $\mathrm{L}^{1}$ presence, was shifted to more negative values; this effect is more evident at higher concentrations. These results indicate that $\mathrm{L}^{1}$ behaved mainly as a cathodic inhibitor $[45,46]$. The results in Table 4 show that the differences in $E_{\text {corr }}$ values between the inhibited and the uninhibited systems are generally less than $85 \mathrm{mV}$. This implies that the tested compound is a mixed-type inhibitor with, predominantly, cathodic inhibition at higher concentrations [47].

In other words, $\mathrm{L}^{1}$ compound inhibits mild steel anodic dissolution in $1 \mathrm{M} \mathrm{HCl}$, and delays the cathodic reduction reaction associated with hydrogen evolution. The values variation in the anodic Tafel slope, $\beta \mathrm{a}$, in the inhibitor presence, can be attributed to the chloride ion molecules or inhibitors adsorption onto the mild steel surface, or to the appearance of certain redox process involving the Fe inhibitor complex on steel active sites [48-50]. Tafel slopes values also vary with the inhibitor concentrations. These remarks indicate that $\mathrm{L}^{1}$ inhibitive action includes some changes in the corrosion reactions mechanism. 
According to the polarization measurements, the inhibition efficiency increases with higher inhibitor concentrations, and reaches a maximum value of $83.83 \%$, at $7.5 \times 10^{-5} \mathrm{M}$.

Electrochemical impedance spectroscopy measurements (EIS)

EIS experimental data, such as the solution resistance $\left(R_{s}\right)$, the charge-transfer resistance $\left(R_{c t}\right)$, the double layer capacitances $\left(C_{d l}\right)$, the constant phase element $(\mathrm{CPE})$, inhibition efficiency, $\mathrm{IE}_{\mathrm{R}}(\%)$, and the surface coverage $(\theta)$, for mild steel corrosion, in $\mathrm{L}^{1}$ absence and presence, at $298 \mathrm{~K}$, are summarized in Table 5 . The impedance spectra for mild steel, in a $1 \mathrm{M} \mathrm{HCl}$ medium without and with $\mathrm{L}^{1}$, with different concentrations, are presented as Nyquist plots in Fig. 3. The results confirm that $\mathrm{L}^{1}$ successfully inhibited mild steel (X48) surface corrosion [51]. In Table 5, the charge-transfer resistance $\left(\mathrm{R}_{\mathrm{ct}}\right)$ value increased with higher inhibitor concentrations, showing substantial surface coverage by the $\mathrm{L}^{1}$ inhibitor, through strong bonding with the X48 surface. By increasing the inhibitor concentration, Cdl values tended to decrease, which may be due to the reduction in local dielectric constant and/or to an increase in the electrical double layer thickness [52-56].

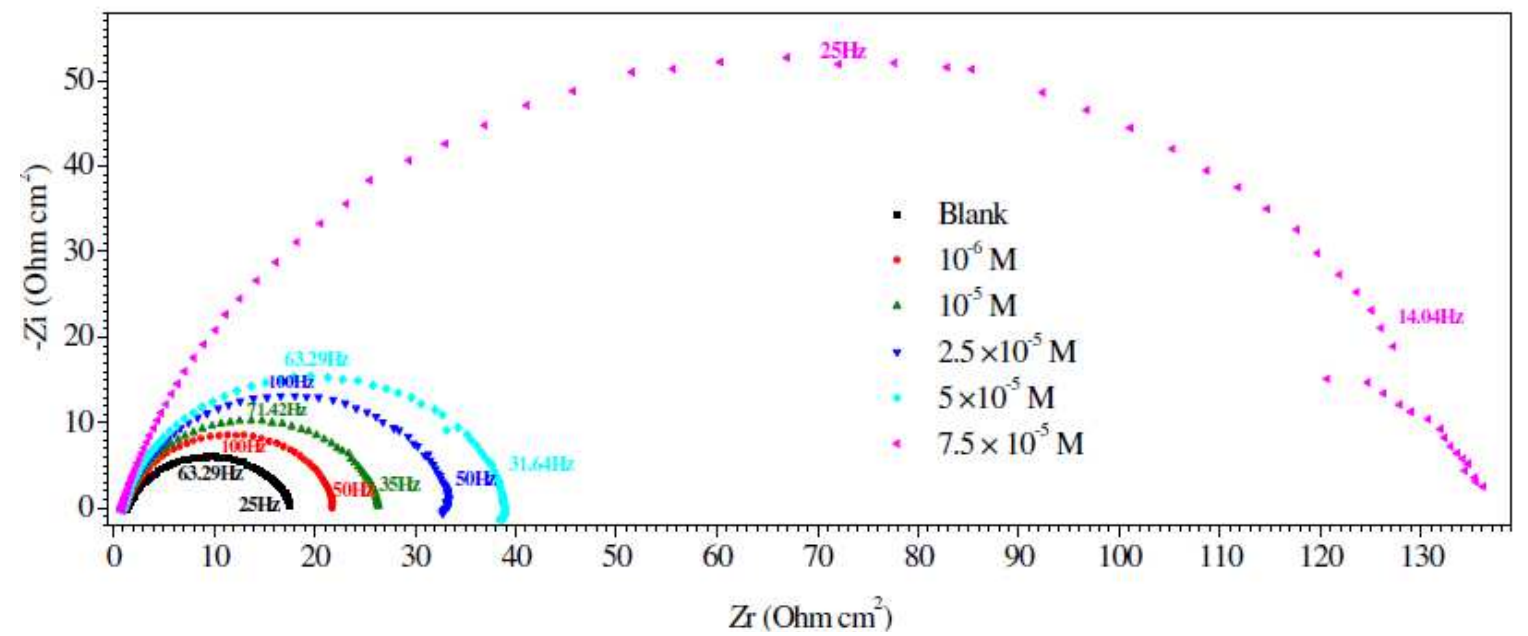

Figure 3. Nyquist diagrams for mild steel in $1 \mathrm{M} \mathrm{HCl}$ containing different Schiff base compound concentrations, at $25^{\circ} \mathrm{C}$.

Table 5. Electrochemical impedance parameters for mild steel in $1 \mathrm{M} \mathrm{HCl}$, with and without Schiff base compound, with various concentrations, at $25^{\circ} \mathrm{C}$.

\begin{tabular}{|c|c|c|c|c|c|c|c|}
\hline \multirow{2}{*}{$\begin{array}{c}\boldsymbol{C}_{\text {inh }} \\
(\mathbf{M})\end{array}$} & \multirow{2}{*}{$\begin{array}{c}\boldsymbol{R}_{\mathbf{s}} \\
\left(\mathbf{\Omega} \mathbf{~ c m}^{2}\right)\end{array}$} & $\begin{array}{c}\boldsymbol{R}_{\mathbf{c t}} \\
\left(\mathbf{\Omega ~ c m}^{2}\right)\end{array}$ & $\begin{array}{c}\boldsymbol{C}_{\mathbf{d l}} \\
\left(\boldsymbol{\mu} \mathbf{F} \mathbf{~ c m}^{-2}\right)\end{array}$ & $\boldsymbol{n}$ & $\begin{array}{c}\boldsymbol{C} \\
\left(\mathbf{S}^{\mathbf{n}} \mathbf{\Omega}^{-1} \mathbf{c m}^{-2}\right)\end{array}$ & $\begin{array}{c}\boldsymbol{I E}_{\boldsymbol{R}} \\
(\boldsymbol{\%})\end{array}$ & $\boldsymbol{\theta}$ \\
\hline blank & 1.320 & 15.07 & 1223.0 & 0.783 & 279.2 & - & - \\
\hline $1.0 \times 10^{-6}$ & 1.190 & 19.62 & 393.5 & 0.848 & 80.78 & 23.19 & 0.23 \\
\hline $1.0 \times 10^{-5}$ & 0.950 & 24.59 & 342.3 & 0.859 & 70.64 & 38.71 & 0.39 \\
\hline $2.5 \times 10^{-5}$ & 1.140 & 31.34 & 264.1 & 0.865 & 50.83 & 51.91 & 0.52 \\
\hline $5.0 \times 10^{-5}$ & 0.980 & 37.09 & 219.4 & 0.868 & 40.39 & 59.36 & 0.59 \\
\hline $7.5 \times 10^{-5}$ & 0.910 & 132.79 & 187.9 & 0.851 & 34.05 & 88.65 & 0.88 \\
\hline
\end{tabular}


Furthermore, the Bode diagrams were plotted using the same experimental data in the Nyquist format (Fig. 4). A new phase angle shift, at a higher frequency range, and a continuous increase in the phase angle shift, with higher inhibitor concentrations, were observed. This phase angle shift is due to the creation of a protective film by the inhibitor on X48 surface, which changed the electrode interfacial structure $[57,58]$. The continuous increase in the phase angle shift is noticeably correlated with the growth of surface coverage by the inhibitor molecules.
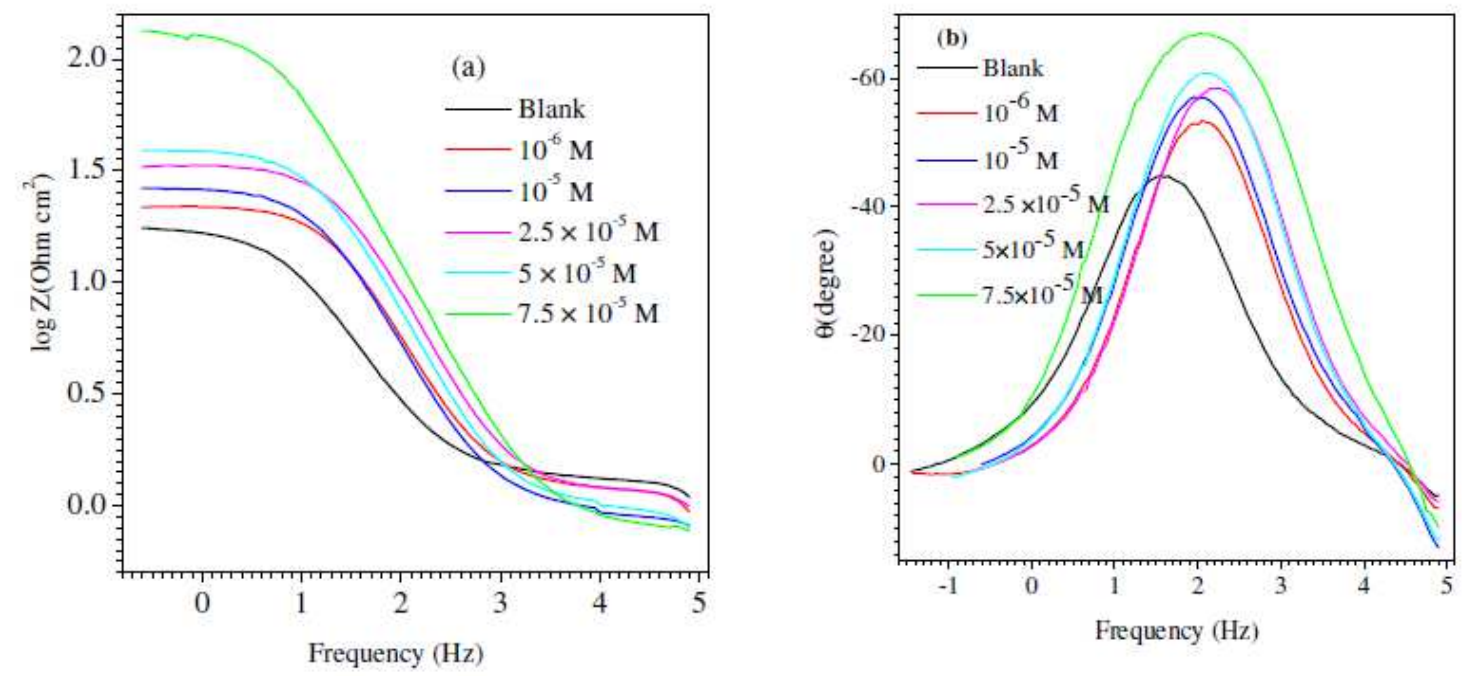

Figure 4. (a) Bode and (b) phase angle plots for mild steel in $1 \mathrm{M} \mathrm{HCl}$, without and with inhibitor $\left(\mathrm{L}^{1}\right)$, with different concentrations, at $25{ }^{\circ} \mathrm{C}$.
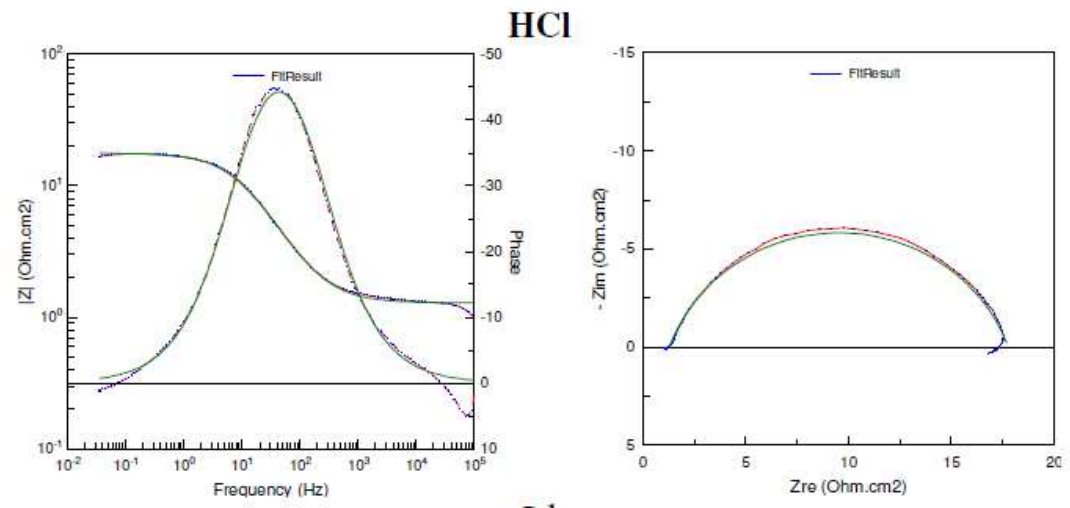

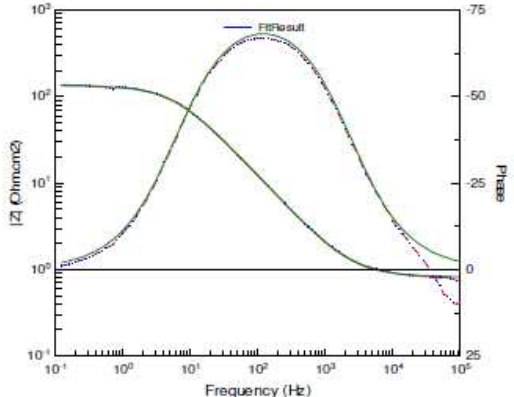

(b)

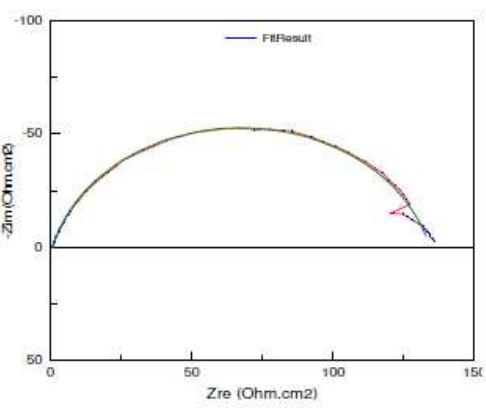

(a)

Figure 5. Impedance diagrams for mild steel in $1 \mathrm{M} \mathrm{HCl}+7.5 \times 10^{-5} \mathrm{M}$ of $\mathrm{L}^{1}$ : Nyquist plot and (b) Bode plot; (....) experimental result; (-) fit result. 
The impedance diagrams were found by fitting (Fig. 5) to the equivalent circuit model shown in Fig. 6, which has been utilized earlier to adequately model the mild steel/acid interface [59-62]. In this equivalent circuit, the solution resistance was shorted by a constant phase element (CPE) that was placed in parallel to the charge transfer resistance. The CPE was utilized in the place of a capacitor to compensate deviations from a perfect dielectric conduct arising from the inhomogeneous nature of the electrode surfaces [63-67].

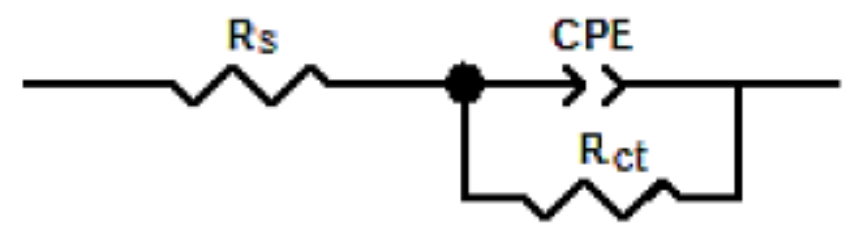

Figure 6. Equivalent circuit of the studied system.

The electrochemical data are presented in Table 5, and show that the inhibitor increased $R_{c t}$ magnitude, with the corresponding decrease in the double layer capacitance $\left(\mathrm{C}_{\mathrm{dl}}\right)$. The increase in $\mathrm{R}_{\mathrm{ct}}$, values, in the inhibiting systems, which corresponds to an increase in the Nyquist semicircle diameter, confirms the corrosion inhibiting effect of both inhibitors. The observed decrease in $C_{\mathrm{dl}}$ values, which normally results from a decrease in the dielectric constant and/or from an increase in the double-layer thickness, can be attributed to the inhibitor molecules adsorption (with a lower dielectric constant compared to that of the displaced adsorbed water molecules) onto the metal/electrolyte interface, thereby protecting the metal from aggressive attacks [68-71].

\section{Temperature effect}

The temperature effect on $\mathrm{L}^{1}$ corrosion inhibition efficiency was studied by polarization curves, in the temperature range from 298 to $308 \mathrm{~K}$, in the absence and presence of the examined Schiff base, with different concentrations. The found data are summarized in Table 6.

From the results, it can be observed that $\mathrm{IE}_{\mathrm{p}}(\%)$ decreases with higher temperatures. The increase in temperature resulted into the adsorbed $\mathrm{L}^{1}$ molecules desorption from the mild steel surface, causing a decrease in $\mathrm{IE}_{\mathrm{p}}(\%)$ [72]. Despite the decrease in $\mathrm{IE}_{\mathrm{p}}(\%)$, it can be said that our product is always effective for mild steel inhibition, because $\operatorname{IE}_{\mathrm{p}}(\%)$ reached the value of $67.5 \%$, at $328 \mathrm{~K}$, with a concentration of $7.5 \times 10^{-5} \mathrm{M}$. These results confirm that the Schiff base molecule is a good inhibitor in the studied temperature range [73-75].

Arrhenius and transition state equations were utilized to calculate the corrosion process activation thermodynamic data, such as apparent activation energy $\left(E_{a}\right)$, enthalpy of activation $\left(\Delta \mathrm{H}_{\mathrm{a}}\right)$ and entropy of activation $\left(\Delta \mathrm{S}_{\mathrm{a}}\right)$. In the Equations (6) and (7), $\mathrm{A}$ is the pre-exponential factor, $\mathrm{i}_{\text {corr }}$ is the corrosion current density, $\mathrm{h}$ is the Plank's constant, $\mathrm{N}_{\mathrm{A}}$ is the Avogadro's number, $\mathrm{T}$ is the absolute temperature and $\mathrm{R}$ is the universal gas constant.

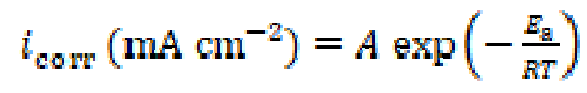




$$
i_{\text {corr }}\left(\mathrm{mA} \mathrm{cm}^{-2}\right)=\frac{R T}{N_{\mathrm{A}} h} \exp \left(\frac{\Delta S \mathrm{a}}{R}\right) \exp \left(-\frac{\Delta H \mathrm{a}}{R T}\right)
$$

Table 6. Polarization data for mild steel in $1 \mathrm{M} \mathrm{HCl}$, without and with the synthesized Schiff base, with different concentrations, and at various temperatures.

\begin{tabular}{|c|c|c|c|c|c|c|}
\hline \multirow[b]{2}{*}{$C_{\mathrm{inh}}(\mathrm{M})$} & \multicolumn{3}{|c|}{$298 \mathrm{~K}$} & \multicolumn{3}{|c|}{$308 \mathrm{~K}$} \\
\hline & $\begin{array}{c}-E_{\text {corr }} \\
(\mathrm{mV} / \mathrm{ECS})\end{array}$ & $\begin{array}{c}i_{\text {corr }} \\
\left(\mathrm{mA} \mathbf{c m}^{-2}\right)\end{array}$ & $\begin{array}{l}I E_{\mathrm{p}} \\
(\%)\end{array}$ & $\begin{array}{c}-E_{\text {corr }} \\
(\mathrm{mV} / \mathrm{ECS})\end{array}$ & $\begin{array}{c}i_{\text {corr }} \\
\left(\mathrm{mA} \mathbf{c m}^{-2}\right)\end{array}$ & $\begin{array}{l}I E_{\mathrm{p}} \\
(\%)\end{array}$ \\
\hline Blank & 554 & 1.67 & - & 595 & 7.15 & - \\
\hline $1.0 \times 10^{-6}$ & 636 & 1.20 & 28.14 & 597 & 2.89 & 60.51 \\
\hline $1.0 \times 10^{-5}$ & 626 & 0.98 & 41.31 & 628 & 2.59 & 64.61 \\
\hline $2.5 \times 10^{-5}$ & 565 & 0.50 & 70.05 & 606 & 2.32 & 68.30 \\
\hline $5.0 \times 10^{-5}$ & 560 & 0.41 & 75.44 & 624 & 2.20 & 69.94 \\
\hline $7.5 \times 10^{-5}$ & 565 & 0.27 & 83.83 & 606 & 1.43 & 80.46 \\
\hline \multirow[b]{2}{*}{$C_{\text {inh }}(\mathbf{M})$} & \multicolumn{3}{|c|}{$318 \mathrm{~K}$} & \multicolumn{3}{|c|}{$328 \mathrm{~K}$} \\
\hline & $\begin{array}{c}-E_{\text {corr }} \\
(\mathrm{mV} / \mathrm{ECS})\end{array}$ & $\begin{array}{c}i_{\text {corr }} \\
\left(\mathrm{mA} \mathrm{cm}^{-2}\right)\end{array}$ & $\begin{array}{l}I E_{\mathrm{p}} \\
(\%)\end{array}$ & $\begin{array}{c}-E_{\text {corr }} \\
(\mathrm{mV} / \mathrm{ECS})\end{array}$ & $\begin{array}{c}i_{\text {corr }} \\
\left(\mathrm{mA} \mathrm{cm}^{-2}\right)\end{array}$ & $\begin{array}{l}I E_{\mathrm{p}} \\
(\%)\end{array}$ \\
\hline Blank & 571 & 7.32 & - & 621 & 8.74 & - \\
\hline $1.0 \times 10^{-6}$ & 599 & 3.64 & 49.09 & 583 & 4.8 & 45.08 \\
\hline $1.0 \times 10^{-5}$ & 595 & 3.09 & 56.67 & 594 & 4.58 & 47.59 \\
\hline $2.5 \times 10^{-5}$ & 595 & 3.04 & 57.48 & 590 & 4.32 & 50.57 \\
\hline $5.0 \times 10^{-5}$ & 596 & 1.92 & 73.14 & 584 & 3.43 & 60.75 \\
\hline $7.5 \times 10^{-5}$ & 594 & 1.90 & 73.42 & 606 & 2.84 & 67.50 \\
\hline
\end{tabular}

According to the data showed in Table 7 , the plots of $\ln \left(\mathrm{i}_{\text {corr }}\right)$ vs. $1 / \mathrm{T}$ and $\ln$ $\left(\mathrm{i}_{\text {corr }} / \mathrm{T}\right.$ ) versus $1 / \mathrm{T}$ (Fig. 7) give straight lines. The $\mathrm{E}_{\mathrm{a}}, \Delta \mathrm{H}_{\mathrm{a}}$ and $\Delta \mathrm{S}_{\mathrm{a}}$ parameters were calculated from the slopes and intercepts of the lines, and the obtained data are given in Table 8. It is evident from Table 7 that $E_{a}$ value for mild steel corrosion in $\mathrm{L}^{1}$ presence is greater than in its absence, which indicates the inhibitor molecules physical adsorption onto the metal surface. According to the literature [76-79], the inhibitor physical adsorption onto the metal surface leads to the formation of a barrier between the latter and the corrosive medium, blocking the charge transfer, and thereby reducing the metal reactivity in the corrosion electrochemical reactions [80]. On the other hand, a diminution in inhibition efficiency with the rise in temperature, with an analogous increase in corrosion activation energy in the inhibitor presence, compared to when it is absent, is normally interpreted as being due to the creation of an adsorption layer of physical nature $[57,79,81] . \Delta S_{a}$ value increases in $L^{1}$ presence. The negative increment of the entropy of activation reflects the inhibitor formation of an ordered stable layer on the mild steel surface $[79,80] . \Delta \mathrm{H}_{\mathrm{a}}$ value is higher in the inhibitor presence. $\Delta \mathrm{H}_{\mathrm{a}}$ positive signs reflect the endothermic nature of mild steel dissolution process, and suggest that the mild steel dissolution rate is slower in $\mathrm{L}^{1}$ presence [82]. It can be noticed that $\mathrm{E}_{\mathrm{a}}$ and $\Delta \mathrm{H}_{\mathrm{a}}$ values vary in the same way, permitting to verify the known thermodynamic equation between them [82]. 
Table 7. Activation parameters for $\mathrm{X} 48$ in $1 \mathrm{M} \mathrm{HCl}$, in $\mathrm{L}^{1}$ absence and presence, with different concentrations.

\begin{tabular}{|c|c|c|c|}
\hline $\begin{array}{c}\boldsymbol{C}_{\text {inh }} \\
(\mathbf{M})\end{array}$ & $\begin{array}{c}\boldsymbol{E}_{\mathbf{a}} \\
\left(\mathbf{k J ~ m o l} \mathbf{~}^{\mathbf{1}}\right)\end{array}$ & $\begin{array}{c}\Delta \boldsymbol{H}_{\mathbf{a}} \\
\left(\mathbf{k J ~ m o l}^{\mathbf{1}}\right)\end{array}$ & $\begin{array}{c}\Delta \boldsymbol{S}_{\mathbf{a}} \\
\left(\mathbf{J ~ m o l}^{\mathbf{1}} \mathbf{K}^{\mathbf{- 1}}\right)\end{array}$ \\
\hline blank & 36.49 & 33.37 & -130.04 \\
\hline $1.0 \times 10^{-6}$ & 39.92 & 36.71 & -120.44 \\
\hline $1.0 \times 10^{-5}$ & 41.08 & 38.21 & -109.29 \\
\hline $2.5 \times 10^{-5}$ & 51.84 & 48.63 & -86.03 \\
\hline $5.0 \times 10^{-5}$ & 56.03 & 52.76 & -70.88 \\
\hline $7.5 \times 10^{-5}$ & 61.05 & 57.70 & -59.18 \\
\hline
\end{tabular}

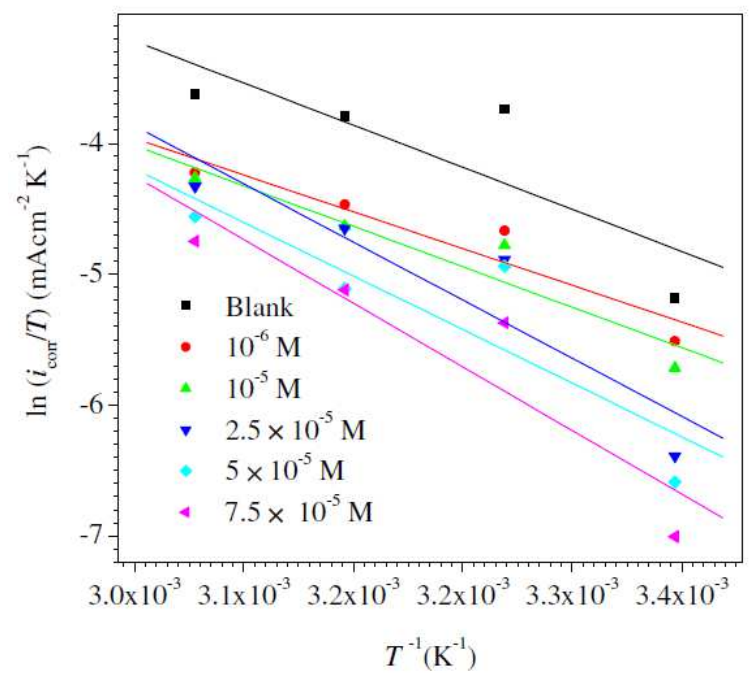

Figure 7. Arrhenius plots for mild steel in $1 \mathrm{M} \mathrm{HCl}$, without and with $\mathrm{L}^{1}$, with different concentrations.

\section{Adsorption isotherms}

The mode and degree of interaction between an inhibitor and a metal surface have been extensively studied by the application of adsorption isotherms. The adsorption of an organic molecule occurs because the interaction energy between an inhibitor and a metal surface is greater than that between the water molecules and a metal surface [82]. To find the adsorption isotherms, the degree of surface coverage $(\theta)$ was determined as a function of the inhibitor concentration. The $\theta$ data were then plotted to fit the greatest appropriated adsorption model $[83,84]$. Fig. 8 presents the dependency of the $\mathrm{C}_{\mathrm{inh}} / \theta$ relationship as a function of the corrosion inhibitor concentration $\left(\mathrm{C}_{\mathrm{inh}}\right)$ for $\mathrm{L}^{1}$. Graphs yielded a good fitting with a correlation factor of 0.99 , which indicates that the compound under study obeyed an adsorption isotherm of the Langmuir kind:

$$
\frac{\mathrm{C}_{\mathrm{inh}}}{\theta}=\frac{1}{\mathrm{~K}_{\mathrm{ads}}}+\mathrm{C}_{\mathrm{inh}}
$$

where $\mathrm{C}_{\mathrm{inh}}$ is the inhibitor concentration, in the test solution total volume and $\mathrm{K}_{\mathrm{ads}}$ is the equilibrium adsorption constant complexed in a chemical reaction. Some authors have correlated the Langmuir isotherm with the contact of adsorbed species with the metallic surface [85, 86]. Data trend indicates that inhibitory molecules are adsorbed onto the metal surface to form a film that insulates it the from the corrosive environment. $\mathrm{K}_{\mathrm{ads}}$ values decreased as temperature increased 
(Table 8), which indicates the presence of a rearrangement and a detachment of the corrosion inhibitor molecules from the metallic surface, with a consequent decay in the inhibitor efficiency. The adsorption equilibrium constant $\left(\mathrm{K}_{\mathrm{ads}}\right)$ is related to the standard free energy of adsorption $\left(-\Delta \mathrm{G}_{\mathrm{ads}}^{\circ}\right)$, as shown in equation (9) $[59,87]$.

$K_{\mathrm{adz}}=\frac{1}{55.5} \exp \frac{\left(-\Delta G_{\mathrm{adz}}^{0}\right)}{R T}$

where $\mathrm{R}$ is the gas constant $\left(8.314 \mathrm{~J} \mathrm{~K}^{-1} \mathrm{~mol}^{-1}\right)$, $\mathrm{T}$ is the absolute temperature $(\mathrm{K})$, and the 55.5 value is the water concentration in a solution, expressed in $\mathrm{M}$ [87].

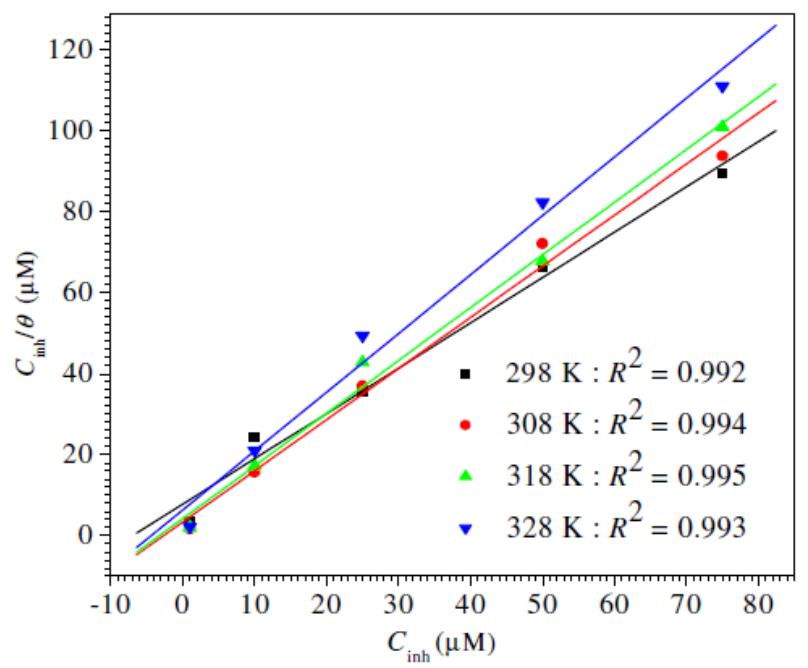

Figure 8. Langmuir adsorption plots for mild steel in $1 \mathrm{M} \mathrm{HCl}$ containing a Schiff base compound, with different concentrations, at various temperatures (from $298 \mathrm{~K}$ to $328 \mathrm{~K}$ ).

The $-\Delta G_{\text {ads }}^{\circ}$ values are also given in Table 8 . The negative $-\Delta G_{\text {ads }}^{\circ}$ values indicate that the inhibitor molecule adsorption onto the steel surface is a spontaneous process. Generally, $-\Delta \mathrm{G}_{\text {ads }}^{\circ}$ values up to $-20 \mathrm{~kJ} \mathrm{~mol}^{-1}$ are consistent with the electrostatic interaction between the charged molecules and the charged metal (physical adsorption), while those more negative than $-40 \mathrm{~kJ} \mathrm{~mol}^{-1}$ involve sharing or transfer of electrons from the inhibitor molecules to the metal surface, to form a coordinate type of bond (chemisorption) $[58,88]$. In the present study, calculated $\Delta \mathrm{G}_{\text {ads }}^{\circ}$ values (between 44.18 and $45.51 \mathrm{~kJ} \mathrm{~mol}^{-1}$ ) indicate that the adsorption mechanism of the prepared cationic surfactants on mild steel in a $1 \mathrm{M} \mathrm{HCl}$ solution is chemical adsorption [89].

Thermodynamic parameters are important to further understand the inhibitor adsorption process onto the steel/solution interface. The standard adsorption enthalpy $\left(\mathrm{AH}^{\circ}{ }^{\circ}\right.$ ds $)$ could be calculated on the basis of the Van't Hoff equation (10).

$$
\ln K_{\mathrm{ad} s}=\ln \frac{1}{55.5}-\frac{\Delta H_{\mathrm{gds}}^{\circ}}{n T}+\frac{\Delta S_{\mathrm{gds}}^{\circ}}{R}
$$

Fig. 9 represents the In $\mathrm{K}_{\text {ads }}$ plots versus $1 / T$ for $\mathrm{L}^{1}$ adsorption, in a hydrochloric acid solution. The obtained lines represent a good linear relationship (the linear correlation coefficient is 0.996 , with a slope of $\left(-\frac{\Delta H_{\mathrm{ada}}^{0}}{R}\right)$ ) and an intercept 
of $\left[\ln \frac{1}{55.5}+\frac{\Delta S_{\mathrm{ads}}^{0}}{R}\right] . \mathrm{K}_{\mathrm{ads}}, \Delta \mathrm{H}_{\mathrm{ads}}^{0}$ and $\Delta \mathrm{S}_{\mathrm{ads}}^{0}$ values are listed in Table 8 . The distinction between physisorption and chemisorption is based on $\Delta \mathrm{H}_{\text {ads }}^{0}$ absolute value. For a physisorption process, the enthalpy of adsorption should be equal to or lower than $40 \mathrm{~kJ} \mathrm{~mol}^{-1}$; while, for chemisorption, it should be equal to or higher than $100 \mathrm{~kJ} \mathrm{~mol}^{-1}$ [90-92]. The calculated $\Delta \mathrm{H}_{\mathrm{ads}}^{0}$ value for $\mathrm{L}^{1}$ is lower than $40 \mathrm{~kJ}$ $\mathrm{mol}^{-1}$. Based on these results, it is apparent that the $\mathrm{L}^{1}$ adsorption mode onto the metal surface is, essentially, physisorption [93]. The $\Delta \mathrm{H}_{\text {ads }}^{0}$ negative value for $\mathrm{L}^{1}$ implies that the orderliness caused by this molecule adsorption onto the metal surface is greater than the randomness created by water desorption [94-96].

Table 8. Standard thermodynamic parameters of $\mathrm{L}^{1}$ adsorption onto the $\mathrm{X} 48$ mild steel surface, in a $1 \mathrm{M} \mathrm{HCl}$ solution, at different temperatures.

\begin{tabular}{|c|c|c|c|c|}
\hline$T(\mathbf{K})$ & $\begin{array}{c}K_{\mathrm{ads}} \times 10^{6} \\
\left(\mathbf{M}^{-1}\right)\end{array}$ & $\begin{array}{c}-\Delta G_{\mathrm{zds}}^{0} \\
\left.(\mathrm{~kJ} \mathrm{~mol})^{-1}\right)\end{array}$ & $\begin{array}{c}\Delta H_{\mathrm{ads}}^{0} \\
\left(\mathrm{~kJ} \mathrm{~mol}^{-1}\right)\end{array}$ & $\begin{array}{c}\Delta S_{\mathrm{ads}}^{0} \\
\left(\mathbf{J ~ m o l}^{-1} \mathbf{K}^{-1}\right)\end{array}$ \\
\hline 298 & 1.19 & 44.65 & \multirow{4}{*}{-33.04} & \multirow{4}{*}{38.13} \\
\hline 308 & 0.55 & 44.18 & & \\
\hline 318 & 0.51 & 45.40 & & \\
\hline 328 & 0.31 & 45.51 & & \\
\hline
\end{tabular}

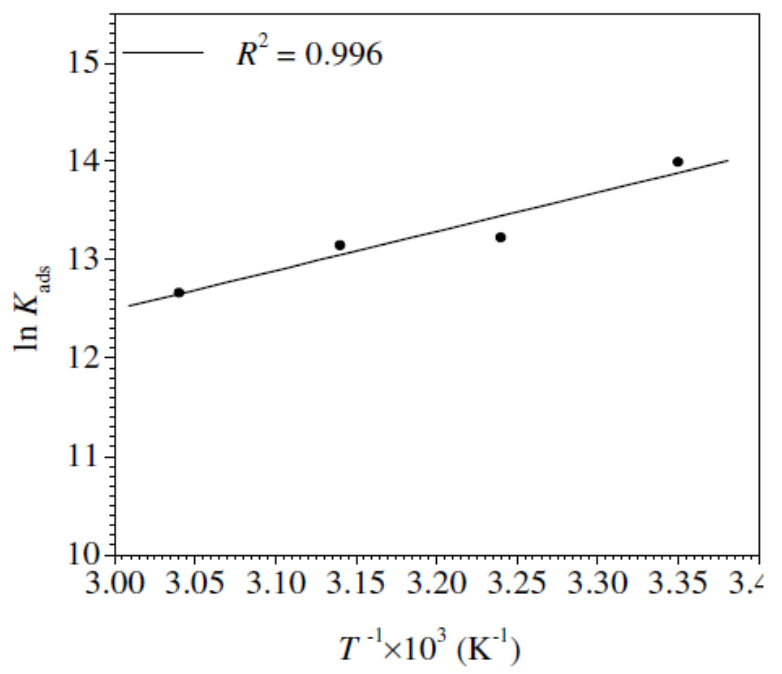

Figure 9. Plot of $\ln K_{\text {ads }}$ against $1 / T$ for $\mathrm{L}^{1}$ (Plot of Vant'Hoff).

\section{Surface characterization}

SEM pictures of the X48 surface were performed to examine the morphology before and after the inhibition process (Fig. 10).

Quantitative data on X48 surface roughness, with and without inhibitor, were not provided by SEM micrograph. Therefore, AFM was used for further study about the MS surface morphology. Fig. 11a-c shows different 2D and 3D images of X48 in various conditions. Fig. 11a shows that X48 surface roughness, before immersion, is $11.681 \mathrm{~nm}$; but Fig. 11b shows that the corroded MS surface has a roughness of $124,332 \mathrm{~nm}$. The X48 surface exposed to the blank solution shows a bumpy structure, with a large number of vicissitudes, due to acid attack. Fig. 11c 
shows that, with the inhibitor addition to the acidic solution, the MS surface morphology changed, due to the creation of an adsorbed protective film [98, 99], causing a decrease in $74.431 \mathrm{~nm}$ of the average surface unevenness.
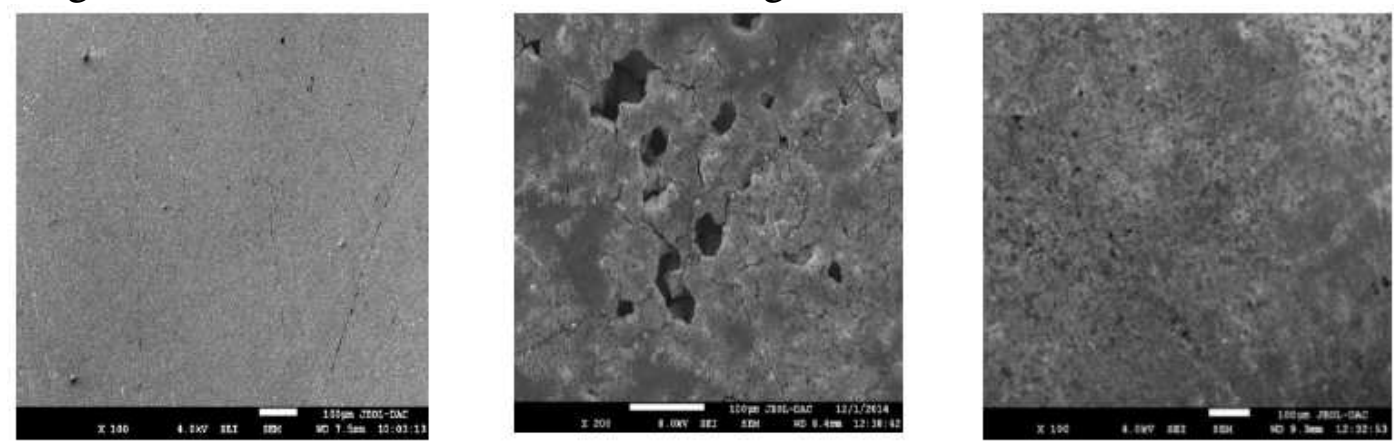

Figure 10. SEM pictures of $X 48$ mild steel samples, at ambient temperature: (a) abraded without immersion in test solutions; (b) after $24 \mathrm{~h}$ immersion in $1 \mathrm{M} \mathrm{HCl}$ withou $\mathrm{L}^{1}$; (c) after $24 \mathrm{~h}$ immersion in $1 \mathrm{M} \mathrm{HCl}$ containing $7.5 \times 10^{-5} \mathrm{M}$ of $\mathrm{L}^{1}$.

(I)
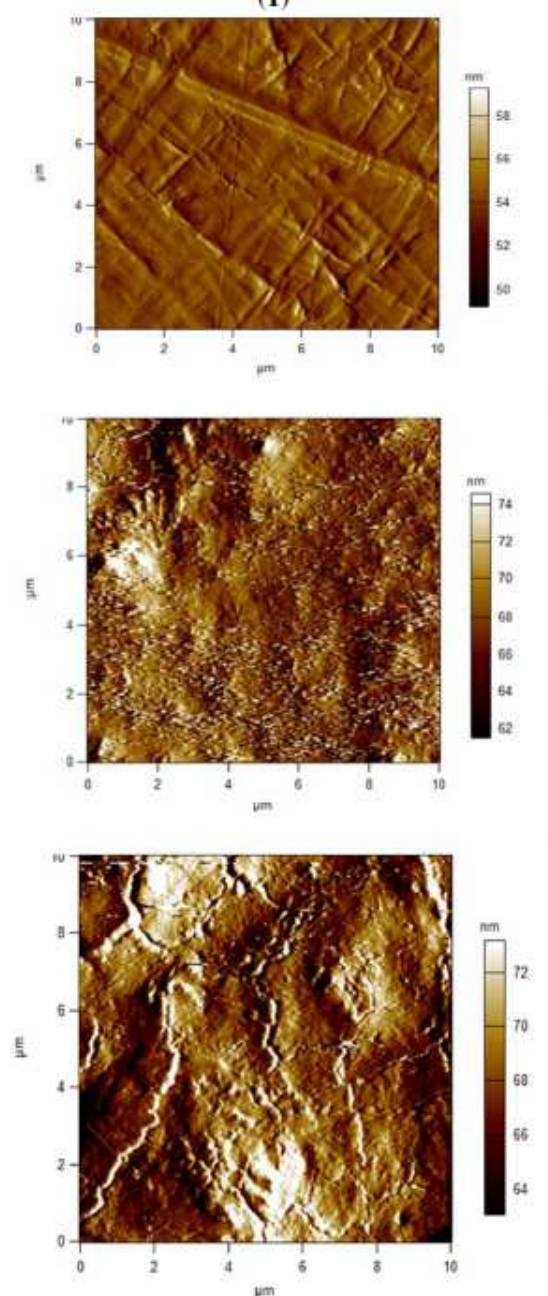

(a)
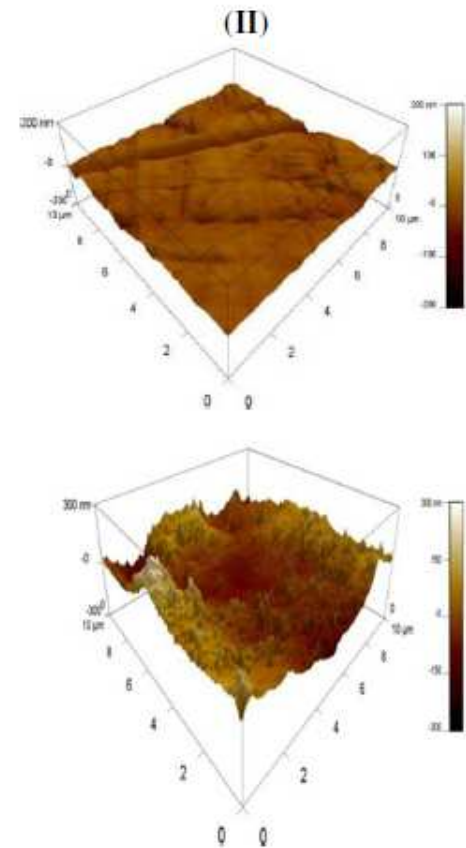

(b)

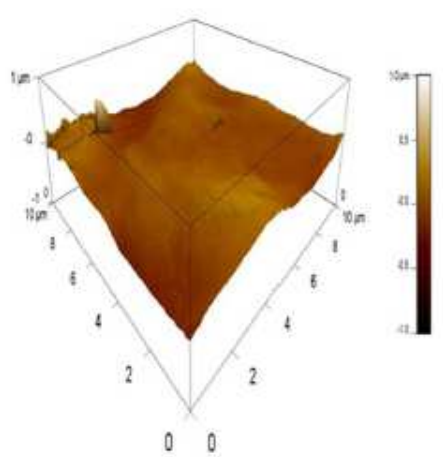

(c)

Figure 11. 2D (I) and 3D (II) AFM pictures of X48 mild steel samples, at ambient temperature: (a) abraded without immersion in test solutions; (b) after $24 \mathrm{~h}$ immersion in $1 \mathrm{M} \mathrm{HCl}$, in the inhibitor absence; (c) after $24 \mathrm{~h}$ immersion in $1 \mathrm{M} \mathrm{HCl}$ containing $\quad 7.5$ $\times 10^{-5} \mathrm{M}$ of $\mathrm{L}^{1}$. 


\section{Theoretical study}

\section{DFT calculations}

Density Functional Theory is certainly the most extensively utilized approach for the design and development of organic inhibitors in the corrosion field. It is worthy of note that this computational method has become very popular in the study of the correlation between molecular structure and corrosion inhibition effect [100]. Interactions of the inhibitor molecule with the metal surface may be involved in the application of the frontier molecular orbital theory. According to this approach, the chemical reactivity of the reactive species is mostly related to the frontier molecular orbitals (FMOs). The study of the highest occupied molecular orbital (HOMO) and the lowest unoccupied molecular orbital (LUMO) is very important in the prediction of the molecules chemical reactivity. The frontier molecular orbital density distributions are shown in Fig. 12.

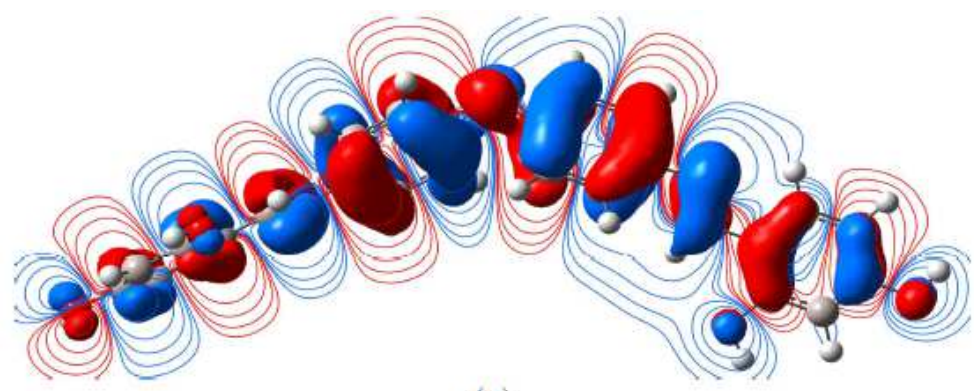

(a)

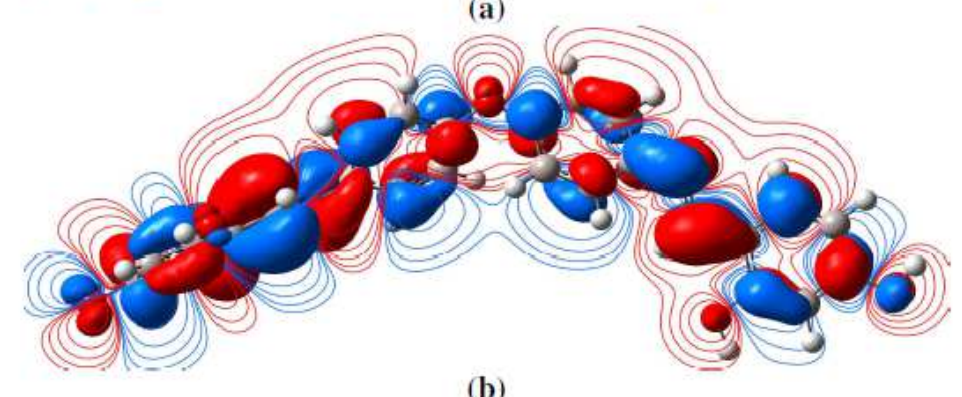

(b)

Figure 12. $\mathrm{L}^{1}$ frontier molecular orbital density distributions: (a) HOMO and (b) LUMO, calculated at the B3LYP/6-31G (d, p) level.

The quantum chemical parameters of the examined inhibitor $\left(\mathrm{L}^{1}\right)$, obtained by DFT, such as the energy of the Highest Occupied Molecular Orbital ( $\mathrm{E}_{\mathrm{HOMO}}$ ), the energy of the Lowest Unoccupied Molecular Orbital (ELUMO), the gap energy $\left(\Delta \mathrm{E}_{\mathrm{gap}}=\mathrm{E}_{\mathrm{LUMO}}-\mathrm{E}_{\mathrm{HOMO}}\right)$ and the dipole moment $(\mu)$, are summarized in Table 9. The HOMO mainly dispersed around the oxygen atoms and nitrogen atoms and benzene rings, whereas the LUMO was mostly localized around nitrogen atoms and benzene rings. Thus, the benzene rings and $\mathrm{N}$ atoms acted as the active centers, donating electrons to the empty Fe d-orbital, to form coordination bonds

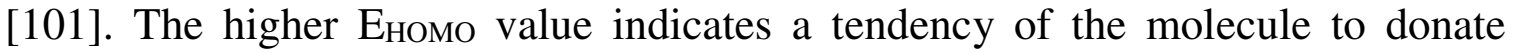
electrons to suitable acceptor molecules with low molecular orbital energy. Thus,

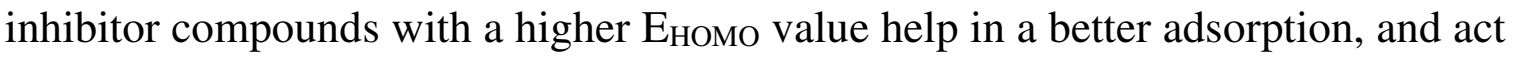
as good inhibitors. Inversely, the LUMO energy ( $\left.\mathrm{E}_{\text {LUMO }}\right)$ indicates the molecule electron accepting ability; the lowest is its value, the higher is the competence to 
accept electrons. As it can be observed from Table 9, $\mathrm{E}_{\mathrm{HOMO}}=-6.35 \mathrm{eV}$ and $\mathrm{E}_{\mathrm{LumO}}$ $=0.61 \mathrm{eV}$, which are in a good correlation between the energy of the frontier molecular orbitals (FMOs) and the inhibition efficiency. The LUMO-HOMO energy gap $\left(\Delta \mathrm{E}_{\mathrm{gap}}\right)$ is a fundamental parameter widely utilized to describe the inhibitor molecules chemical reactivity across the adsorption onto the steel surface. In this way, a low $\Delta \mathrm{E}_{\text {gap }}$ value easily causes a strong chemical change at the inhibitor/steel interface; thus, the molecule adsorption onto the metal surface is much easier [102]. According to our results, it is clear that the $\mathrm{L}^{1}$ protonated form $\left(\Delta \mathrm{E}_{\text {gap }}=0.35 \mathrm{eV}\right)$ could more strongly adsorb onto the metallic surface than the neutral form $\left(\Delta \mathrm{E}_{\mathrm{gap}}=6.96 \mathrm{eV}\right)$. Another important electronic factor considered in the corrosion inhibition study is the dipole moment $(\mu)$. The dipole moment represents the non-uniform distribution of charges on the different atoms in a molecule, which is utilized in the estimation of intermolecular interactions force. A high $\mu$ value may increase the inhibitor adsorption through electronic strength [102]. In the present study (Table 9), $\mathrm{L}^{1}$ has a quite high $\mu$ value $(3.65 \mathrm{D})$, compared with that of the $\mathrm{H}_{2} \mathrm{O}$ dipole moment (1.88 Debye), which shows strong dipole-dipole interactions between the inhibitor molecules and the metallic surface.

Table 9. Schiff base compound quantum chemical parameters calculated using the DFT method, at the B3LYP/6-31G (d, p) basis set.

\begin{tabular}{|c|c|c|}
\hline Quantum parameters & $\mathbf{L}^{\mathbf{1}}$ & $\mathbf{H}_{\mathbf{2}} \mathbf{L}^{\mathbf{1}}$ \\
\hline$E_{\mathrm{HOMO}}(\mathrm{eV})$ & -6.35 & -2.69 \\
\hline$E_{\mathrm{LUMO}}(\mathrm{eV})$ & 0.61 & -2.34 \\
\hline$\Delta E\left(E_{\mathrm{LUMO}}-E_{\mathrm{HOMO}}\right)(\mathrm{eV})$ & 6.96 & 0.35 \\
\hline Dipole moment $\mu(\mathrm{D})$ & 3.65 & 2.64 \\
\hline
\end{tabular}

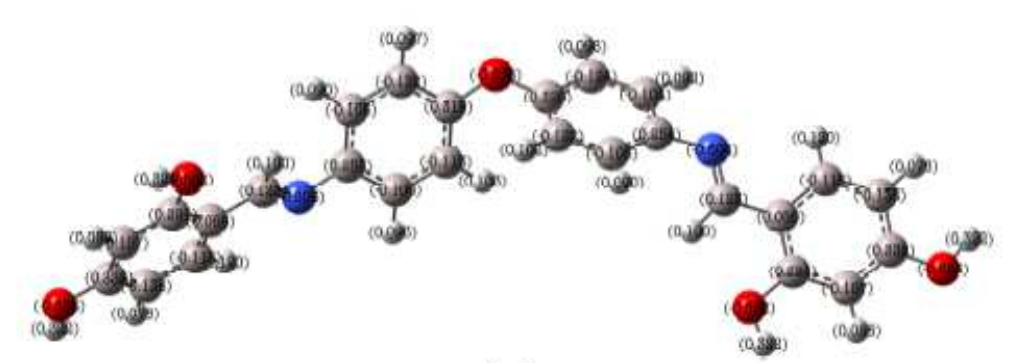

(a)

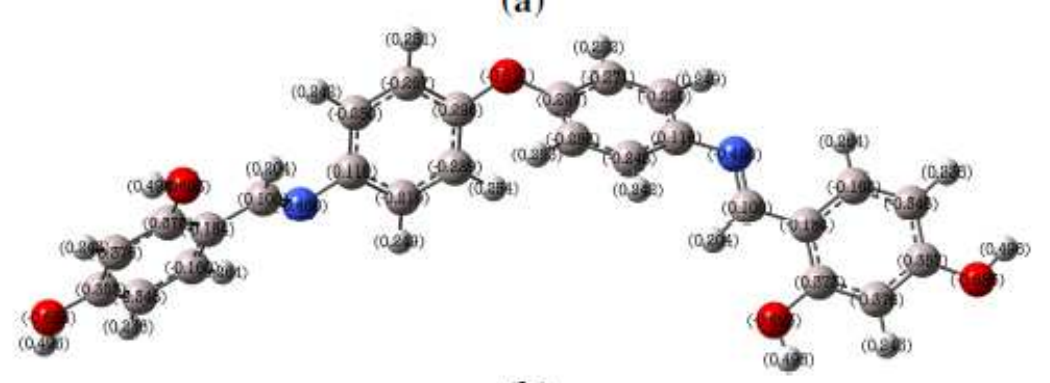

(b)

Figure 13. $\mathrm{L}^{1}$ optimized structure of the inhibitor $\left(\mathrm{L}^{1}\right)$ with (a) Mulliken charges and (b) NBO charges calculated at the B3LYP/6-31 G (d, p) level. 
It is clear, from Fig. 13, that the Mullikan charges for the examined compound show that the electronegative centers in the molecules are mainly located around heteroatoms (oxygen and nitrogen atoms) and some atoms of benzene rings. These sites with improved electron clouds donate electrons to metal atoms, through the adsorption process. Natural bonding orbitals (NBO) investigation offers an important approach to the study of intra and intermolecular attachment and interaction among bonds [103]. To study the interactions between the solid orbitals of one subsystem and the vacant orbitals of another system, the NBO values are calculated and presented in Fig. 13.

$\mathrm{L}^{1}$ nitrogen and oxygen atoms and also some carbon atoms have negative charges, which are the most preferred positions for the linking to the mild steel surface through contributing electrons. However, some other carbon atoms (positive charges) can receive the electrons from metal.

Molecular electrostatic potential (MEP) is related to the electronic density, and it is a very suitable factor for understanding positions for electrophilic attack and nucleophilic reactions. $\mathrm{L}^{1}$ contour and total electron density surface mapped with molecular electrostatic potential (MEP) are presented in Fig. 14. MEP negative (red) areas are related to nucleophilic reactivity, and the positive (blue) areas to electrophilic reactivity. It is clear that more electron rich regions are mainly situated nearby heteroatoms and conjugated double bonds. As noticed, the formation of a chelate on the mild steel surface, by the transference of ring electrons from benzene groups to the iron atom orbital d, originates a covalent bond coordinated by chemical adsorption. In this way, mild steel action as an electrophile is likely to attract the inhibitory molecule negatively charged sites, and $\mathrm{L}^{1}$ nucleophilic centers are normally heteroatoms with free electron pairs, functional electronegative groups and $\pi$-electrons in the conjugated double bonds, which are readily available to form chemical bonds.

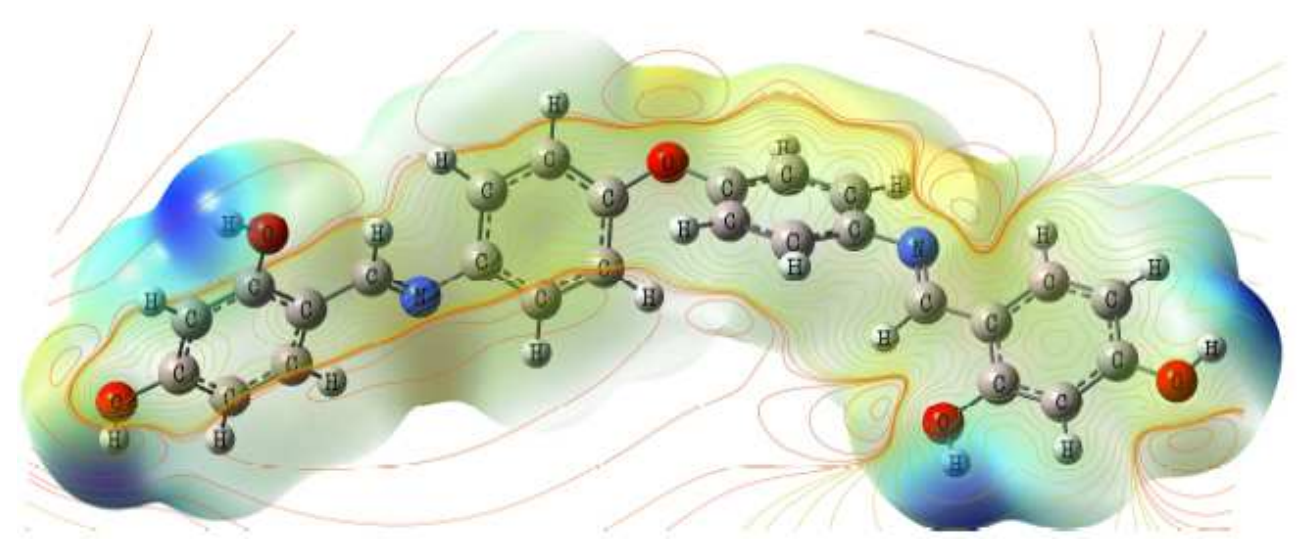

Figure 14. $\mathrm{L}^{1}$ contour map of molecular electrostatic potential (MEP) calculated at B3LYP/6-31G (d, p) level for the compound.

$\underline{\text { Molecular dynamics simulations }}$

Molecular dynamics simulations were performed to study $\mathrm{L}^{1}$ adsorption behavior

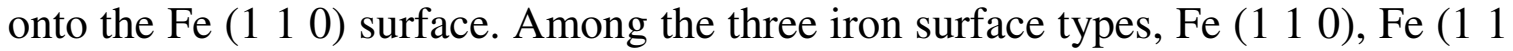
1) and Fe (1 00 ), the last two have relatively open structures, while Fe $\left(\begin{array}{lll}1 & 1 & 0\end{array}\right)$ 
surface has a more stable shape with a packed density [104, 105]. The total energy, Vander Waals energy, average total energy, electrostatic energy and intermolecular energy, for the $\mathrm{L}^{1}$-Fe $\left(\begin{array}{lll}1 & 1 & 0\end{array}\right)$ systems under study, were calculated by adsorption locator module, and are given in Fig. 15. The total energy is defined as the sum of the energies of the adsorbed molecules, namely the rigid adsorption energy and the deformation energy. In this study, the adsorption energy (kcal mol ${ }^{-1}$ ) shows the released (or necessary) energy when the relaxed inhibitor molecules are adsorbed onto the metal surface. The contact between the inhibitor molecules $\left(\mathrm{L}^{1}\right)$ and the iron surface, as well as the best adsorption configuration for that compound, are shown in Fig. 16.

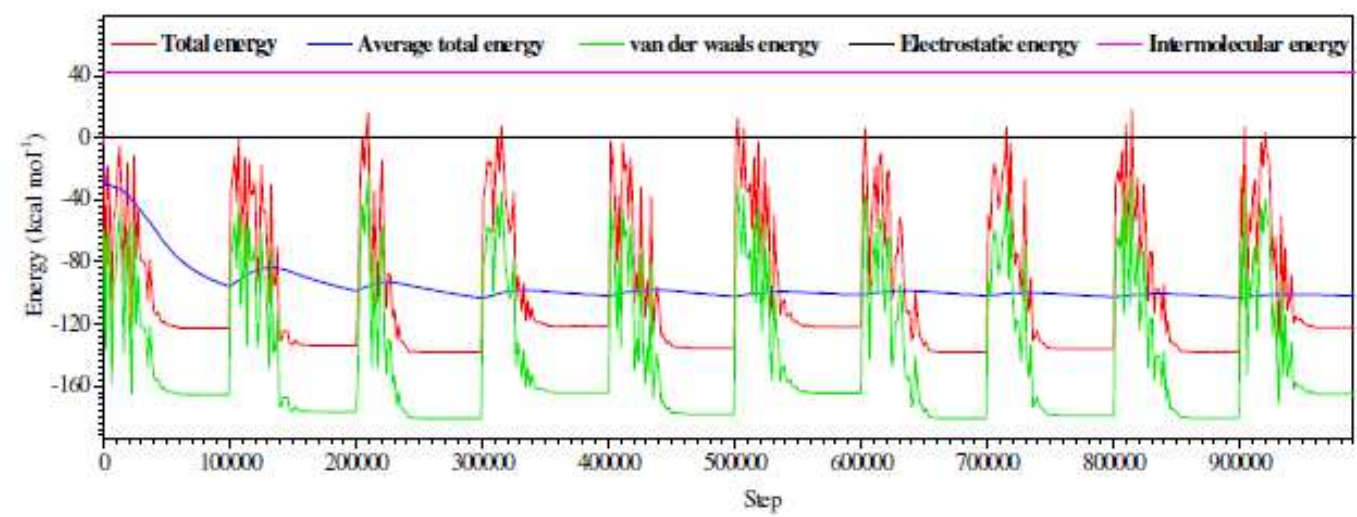

Figure 15. Energy distribution during the inhibitor/Fe $\left(\begin{array}{lll}1 & 1 & 0\end{array}\right)$ system optimization process for $\mathrm{L}^{1}$.

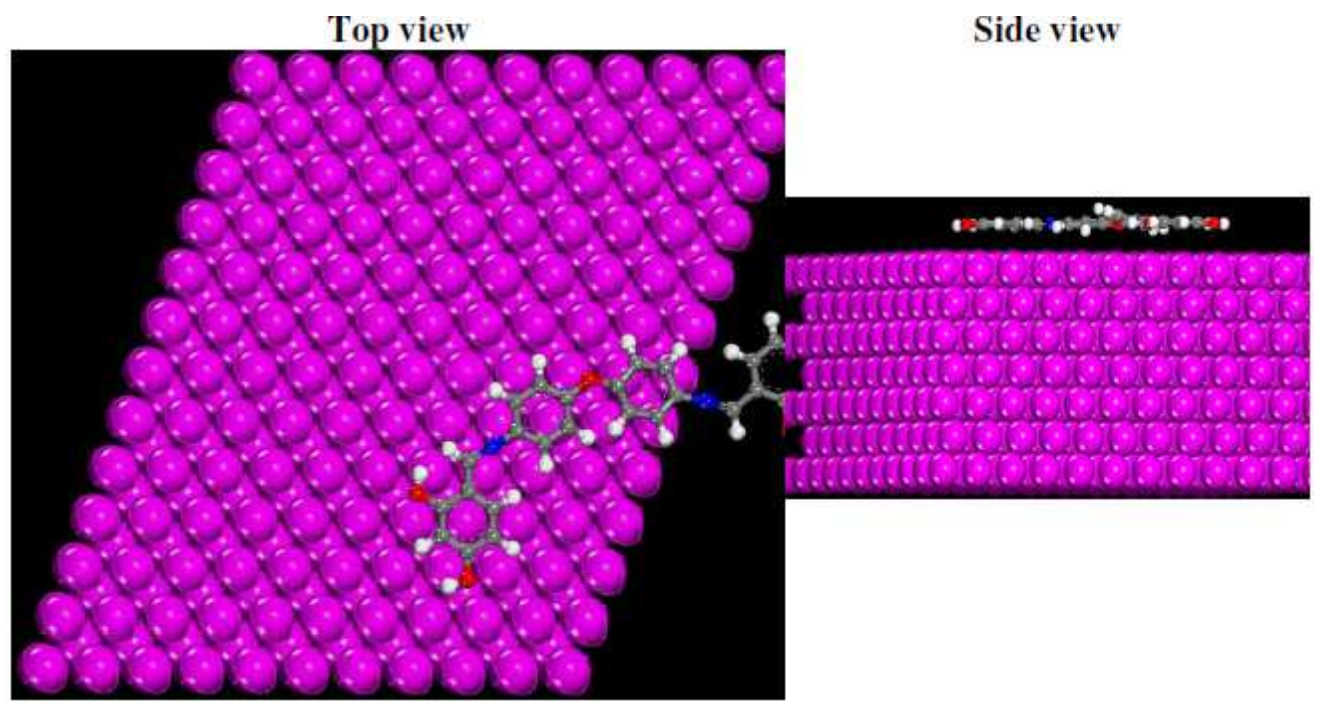

Figure 16. $\mathrm{L}^{1}$ equilibrium adsorption configurations on $\mathrm{Fe}\left(\begin{array}{lll}1 & 1 & 0\end{array}\right)$ surface, obtained by molecular dynamic simulations.

It is clearly seen from Fig. 16 that the inhibitor molecules adsorb onto the Fe (1 1 $0)$ surface with, practically, a parallel disposition between the rigid molecular structure and the metal surface, confirming the great contact between the inhibitor molecule and Fe atoms, by creating a protective film on the Fe (llll 10$)$ area.

The simulation parameters are shown in Table 10. The large interaction energy negative value indicates that the interaction between the inhibitor molecules and 
the Fe surface is physically powerful. It is clear that the $\mathrm{L}^{1}$-Fe system has a large negative interaction energy $\left(-349.08 \mathrm{kcal} \mathrm{mol}^{-1}\right)$. In addition, it is important to note that the inhibitor molecules adsorption aptitude onto the Fe surface may be forecasted by the binding energy shown in Table 10.

Table 10. Outputs and descriptors calculated by the molecular dynamic simulations for $\mathrm{L}^{1}$ derivative adsorption onto the Fe $\left(\begin{array}{lll}1 & 1 & 0\end{array}\right)$ surface.

\begin{tabular}{|c|c|c|c|c|}
\hline System & $\begin{array}{c}\text { Interaction } \\
\text { energy } \\
\left(\mathbf{k c a l ~ m o l}^{-1}\right)\end{array}$ & $\begin{array}{c}\text { Rigid adsorption } \\
\text { energy } \\
\left(\mathbf{k c a l ~ m o l}^{-1}\right)\end{array}$ & $\begin{array}{c}\text { Deformation } \\
\text { energy } \\
\left(\mathbf{k c a l ~ m o l}^{-1}\right)\end{array}$ & $\begin{array}{c}\text { Binding energy } \\
\left(\mathbf{k c a l ~ m o l}^{-1}\right)\end{array}$ \\
\hline $\mathrm{L}^{1}-\mathrm{Fe}\left(\begin{array}{lll}1 & 1 & 0\end{array}\right)$ & -349.08 & -236.96 & -112.12 & 349.08 \\
\hline
\end{tabular}

The adsorption system $\left(\mathrm{L}^{1}-\mathrm{Fe}\right)$ binding energy is $349.08 \mathrm{kcal} \mathrm{mol}^{-1}$, which shows that this system is very stable, and that it has high inhibitory efficiency. According to the quantum chemistry study, the tested oxygen and nitrogen atoms can give electrons to the unoccupied "d" iron orbital, to form coordination bonds, while the aromatic rings $\pi$ orbital can accept electrons from the " $d$ " iron orbital, to form coordination bonds.

\section{Conclusions}

The obtained results allowed us to conclude that:

- the work done on the Schiff base $\left(\mathrm{L}^{1}\right)$ revealed that it acts as a good corrosion inhibitor. Its inhibitory power increased with higher concentrations, reaching a maximum values of $92.19 \%$ (gravimetric), $83.83 \%$ (polarization curves) and $88.65 \%$ (EIS), at $7.5 \times 10^{-5} \mathrm{M}$;

- potentiodynamic polarization curves show that the tested compound is a mixedtype inhibitor with, predominantly, cathodic inhibition, with higher concentrations;

- corrosion rate decreases with higher inhibitor concentrations;

- the electrochemical impedance spectroscopy diagrams are in the form of an individual capacitive loop. This inhibitor addition to a $1 \mathrm{M} \mathrm{HCl}$ medium increases the charge transfer resistance, while it reduces the double layer capacity. This result can be attributed to the increase in the thickness of the electric double layer;

- the action of this organic compound is based on a mechanism of simple adsorption onto the mild steel surface, thus blocking the active sites and, therefore, decreasing the corrosion rate. This adsorption onto the metal surface led to the formation of a monolayer, according to the Langmuir isotherm, in the studied temperature range;

- the comparison of the results obtained through the used weighting and electrochemistry methods shows a satisfactory agreement of these results;

- the morphology study of the X48 mild steel surface, in the inhibitor absence and presence, by scanning electron microscopy (SEM) and atomic force microscopy 
(AFM), shows the presence of a protective and adherent layer on the metal surface, which limits the penetration by the electrolyte;

- and the theoretical calculations are in good agreement with the experimental results; they show that these heterocyclic derivatives have interesting molecular structures for the corrosive process inhibition.

\section{References}

1. El Hajjaji F, Belghiti ME, Drissi M, et al. Electrochemical, Quantum Calculations and Monte Carlo Simulation Studies of N1,N2-Bis(1Phenylethylidene) Ethane-1,2-Diamine as a Corrosion Inhibitor for Carbon Steel in a $1.0 \mathrm{M}$ Hydrochloric Acid Solution. Port Electrochim Acta. 2019;37(1):23-42. https://doi.org/10.4152/pea.201901023

2. Emregül KC, Atakol O. Corrosion Inhibition of Mild Steel with Schiff Base Compounds in $1 \mathrm{M} \mathrm{HCl}$. Mater Chem Phys. 2003;82:188-193. https://doi.org/10.1016/S0254-0584(03)00204-9

3. Hosseini MG, Mertens SFL, Ghorbani M, et al. Asymmetrical Schiff bases as inhibitors of mild steel corrosion in sulphuric acid media._Mater Chem Phys. 2003;78: 800-808. https://doi.org/10.1016/S0254-0584(02)00390-5

4. Gilmartin MAT, Hart JP. Sensing with chemically and biologically modified carbon electrodes. Analyst. 1995;120:1029-1045. https://doi.org/10.1039/AN9952001029

5. Gao WT, Zheng Z. Synthetic studies on optically active Schiff-base ligands derived from condensation of 2-hydroxyacetophenone and chiral diamines. Molecules. 2002;7:511-516. https://doi.org/10.3390/70700511

6. Shakir M, Azam M, Azim Y, et al. Synthesis and physicochemical studies on complexes of 1,2-diaminophenyl-N,N'-bis-(2-pyridinecarboxaldimine), (L): A spectroscopic approach on binding studies of DNA with the copper complex. Polyhedron.

2007;26:5513-5518. https://doi.org/10.1016/j.poly.2007.08.032

7. Habibi MH, Montazerozohori M, Lalegani A, et al. Synthesis, structural and spectroscopic properties of a new Schiff base ligand $N, N^{\prime}-$ bis (trifluoromethylbenzylidene) ethylenediamine. J Fluorine Chem. 2006;127:769-773. https://doi.org/10.1016/j.jfluchem.2006.02.014

8. Kannan S, Pillai MRA, Droege PA, et al. Synthesis and crystal structure of a novel trinuclear copper (II) complex from amine-phenol ligand. Inorg Chem Acta. 1997;254:397-400. https://doi.org/10.1016/S00201693(96)05177-8

9. Zarrok H, Oudda H, El Midaoui A, et al. Some new bipyrazole derivatives as corrosion inhibitors for $\mathrm{C} 38$ steel in acidic medium. Res Chem Intermed. 2012;38: 2051-2063. https://doi.org/10.1007/s11164-012-0525-X

10. H. Serrar, M. Larouj, H.L. Gaz, et al. Experimental and Theoretical Studies of the Corrosion Inhibition of 4-amino-2-(4-chlorophenyl)-8-(2, 3dimethoxyphenyl)-6-oxo-2, 6-dihydropyrimido [2, 1-b][1, 3] thiazine-3,7dicarbonitrile on Carbon Steel in a $1.0 \mathrm{M} \mathrm{HCl}$ Solution. Port Electrochim Acta. 2018;36(1):35-52. https://doi.org/10.4152/pea.201801035 
11. Adardour K, Touir R, Ramli Y, et al. Comparative inhibition study of mild steel corrosion in hydrochloric acid by new class synthesized quinoxaline derivatives: part I. Res Chem Intermed. 2013;39:1843-1855. https://doi.org/10.1007/s11164-012-0719-2

12. Emregül KC, Hayvali M. Studies on the effect of vanillin and protocatechualdehyde on the corrosion of steel in hydrochloric acid. Mater Chem Phys. 2004;83:209-216. https://doi.org/10.1016/j.matchemphys.2003.08.030

13. Jarrahpour AA, Motamedifar M, Pakshir K, et al. Synthesis of novel azo Schiff bases and their antibacterial and antifungal activities. Molecules. 2004;9:815-824. https://doi.org/10.3390/91000815

14. Mahindru AM, Fisher JM, Rabinovitz M. Bathocuproine sulphonat: a tissue culture-compatible indicator of copper-mediated toxicity. Nature. 1983;303: 64-65. https://doi.org/10.1038/303064a0

15. Palet PR, Thaker BT, Zele S. Preparation and characterisation of some lanthanide complexes involving a heterocyclic $\beta$-diketone. Indian $\mathrm{J}$ Chem A.1999;38:563-567.

16. Abdallah SM, Mohamed GG, Zayed M, et al. Spectroscopic study of molecular structures of novel Schiff base derived from o-phthaldehyde and 2-aminophenol and its coordination compounds together with their biological activity. Spectrochim Acta A. 2009;73:833-840. https://doi.org/10.1016/j.saa.2009.04.005

17. Fontana M, Staehle K. Advances in corrosion science and technology. 1st ed. New York: Plenum Press; 1970.

18. Kaabi I, Sibous L, Douadi T, et al. X-ray structure of a new ligand: Di[(4phenylimino) 4-diethylsalicylaldehyde] ether and electrochemical study of its copper (II) and cobalt (II) complexes. J Mol Struct. 2015;1084:216-222. https://doi.org/10.1016/j.molstruc.2014.12.023

19. Averseng F, Lacroix PG, Malfant I, et al. Enhanced second harmonic generation on passing from a mono-to a dicopper(II) bis(salicylaldiminato) Schiff base complex. Inorg Chem. 2001;40:3797-3804. https://doi.org/10.1021/ic0013429

20. Aranha PE, Souza JM, Romera S, et al. Thermal behavior of vanadyl complexes with Schiff bases derived from trans- $N, N^{\prime}$-bis (salicylidene)-1,2cyclohexadiamine ( $t$-Salcn). Thermochim Acta. 2007;453:9-13. https://doi.org/10.1016/j.tca.2006.11.001

21. Carcelli M, Ianelli S, Pelagatti P, et al. Structural characterization of a new ligand mode of 2,6-diacetylpyridine bis (semicarbazone), $\mathrm{H}_{2}$ daps. Inorg Chim Acta. 1999;292:121-126. https://doi.org/10.1016/S00201693(99)00166-8

22. Cai YP, Su CY, Xu AW, et al. Syntheses and characterization of copper (II) complexes of bis (acetylacetone) trimethylenediimine. Polyhedron. 2001;20:657-662. https://doi.org/10.1016/S0277-5387(01)00721-5

23. Isse AA, Gennaro A, Vianello E. Electrochemical reduction of Schiff base ligands $\mathrm{H}_{2}$ salen and $\mathrm{H}_{2}$ salophen. Electrochim Acta. 1997;42:2065-2071. https://doi.org/10.1016/S0013-4686(97)85482-5 
24. Carthy PJM, Hovey RJ, Veno K, et al. Inner Complex Chelates. I. Analogs of Bisacetylacetone of Ethylenediimine and its Metal Chelates. J Am Chem Soc. 1955;77:5820-5824. https://doi.org/10.1021/ja01627a011

25. Hirumalaikumar M, Jegannathan S. Inhibition Effects of Nitrones on the Corrosion of Mild Steel in Organic Acid Media. Port Electrochim Acta. 2011;29(1):1-8. https://doi.org/10.4152/pea.201101001

26. Dennington R, Keith T, Millam J. GaussView, Version 4.1.2, Semichem, Inc., Shawnee Mission, KS, 2007.

27. Gaussian 09, Revision A.02, Frisch MJ, Trucks GW, Schlegel HB, et al. Gaussian, Inc., Wallingford CT 2016.

28. .Lee C, Yang W, Parr RG. Development of the Colle-Salvetti correlationenergy formula into a functional of the electron density. Phys Rev B. 1988;37:785-789. https://doi.org/10.1103/PhysRevB.37.785

29. Petersson GA, Bennett A, Tensfeldt TG, et al. A complete basis set model chemistry. I. The total energies of closed-shell atoms and hydrides of the first-row elements. J Chem Phys. 1988;89:2193-2218. https://doi.org/10.1063/1.455064

30. Chafai N, Chafaa S, Benbouguerra K, et al. Synthesis, characterization and the inhibition activity of a new $\alpha$-aminophosphonic derivative on the corrosion of XC48 carbon steel in $0.5 \mathrm{M} \mathrm{H}_{2} \mathrm{SO}_{4}$ : Experimental and theoretical studies. J Taiwan Inst Chem E. 2017;70:331-344. https://doi.org/10.1016/j.jtice.2016.10.026

31. Materials Studio, version 7.0, Accelrys Inc., San Diego, USA, 2013.

32. Xie S, Liu Z, Han G, et al. Molecular dynamics simulation of inhibition mechanism of 3,5-dibromo salicylaldehyde Schiff's base. Comput Theor Chem. 2015;1063:50-62. https://doi.org/10.1016/j.comptc.2015.04.003

33. Baghiani A, Ameni D, Boumerfeg S, et al Studies of antioxidant and Xantine oxidase inhibition potential of root and aerial parts of medicinal plants Capparis spinosa L. Am J Med Sci. 2012;2:25-32. https://doi.org/10.5923/j.ajmms.20120201.06

34. Kilic A, Tas E, Deveci B, et al. Synthesis, electrochemical and in situ spectroelectrochemical studies of new transition metal complexes with two new Schiff-bases containing $\mathrm{N}_{2} \mathrm{O}_{2} / \mathrm{N}_{2} \mathrm{O}_{4}$ donor groups. Polyhedron. 2007;26:4009-4018. https://doi.org/10.1016/j.poly.2007.05.013

35. Felicio RC, Da Silva GA, Ceridorio LF, et al. Tetradentate Schiff base copper (II) complexes. Synth React Inorg Met Org Chem. 1999;29:171-192. https://doi.org/10.1080/00945719909349442

36. Abou-Hussein AA, Linert W. Synthesis, spectroscopic, coordination and biological activities of some organometallic complexes derived from thioSchiff base ligands. Spectrochim Acta A. 2014;117:763-771. https://doi.org/10.1016/j.saa.2013.06.078

37. Annigeri SM, Sathisha MP, Revankar VK. Spectroscopic studies of bridged binuclear complexes of $\mathrm{Co}$ (II), Ni (II), $\mathrm{Cu}$ (II) and $\mathrm{Zn}$ (II). Trans Met Chem. 2007;32:81-87. https://doi.org/10.1007/s11243-006-0131-0

38. Refat MS, El-Deen IM, Ibrahim HK, et al. Synthesis and spectroscopic studies of some transition metal complexes of a novel Schiff base ligands 
derived from 5-phenylazo-salicyladehyde and o-amino benzoic acid. Spectrochim Acta A. 2006;65:1208-1220. https://doi.org/10.1016/j.saa.2006.01.049

39. Issa RM, Khedr AM, Rizk HF. UV-vis, IR and ${ }^{1} \mathrm{H}$ NMR spectroscopic studies of some Schiff bases derivatives of 4-aminoantipyrine. Spectrochim Acta A. 2005;62:621-629. https://doi.org/10.1016/j.saa.2005.01.026

40. Kasumov VT. Synthesis, spectroscopic characterization and ESR studies on electron transfer reactions of bis[N-(2,6-di-tert-butyl-1-hydroxyphenyl) salicylaldiminato]-copper (II) complexes with $\mathrm{PbO}_{2}$ and $\mathrm{PPh}_{3}$. Spectrochim Acta A. 2001;57:1649-1662. https://doi.org/10.1016/S1386-1425(01)004000

41. Kaabi I, Douadi T, Haffar D, et al. Crystal structure of a new pentadentate symmetrical: di[4-(phenylimino) pentan-2-one]ether. Structural and electrochemical studies of its $\mathrm{Co}$ (II), $\mathrm{Ni}$ (II), $\mathrm{Cu}$ (II) and Cd (II) complexes. Trans Met Chem. 2007;31:666-673. https://doi.org/10.1007/s11243-0070229-Z

42. Gili P, Martín Reyes MG, Martín Zarza P, et al. Complexes of Mn(II) and Mn(III) with the Schiff base N-[2-(3-ethylindole)]pyridoxaldimine. Electrochemical study of these and related $\mathrm{Ni}$ (II) and $\mathrm{Cu}$ (II) complexes. Inorg Chim Acta. 1997;255:279-288. https://doi.org/10.1016/S00201693(96)05374-1

43. Yadav M, Sinha RR, Sarkar TK, et al. Application of new isonicotinamides as a corrosion inhibitor on mild steel in acidic medium: Electrochemical, SEM, EDX, AFM and DFT investigations. J Mol Liq. 2015;212:686-698. https://doi.org/10.1016/j.molliq.2015.09.047

44. Tazouti A, Galai M, Touir R, et al. Experimental and theoretical studies formild steel corrosion inhibition in $1.0 \mathrm{M} \mathrm{HCl}$ by three new quinoxalinone $\begin{array}{llll}\text { derivatives. } & \mathrm{J} & \text { Mol 2016;221:815-832. }\end{array}$ https://doi.org/10.1016/j.molliq.2016.03.083

45. Mousavi M, Mohammadalizadeh M, Khosravan A. Theoretical investigation of corrosion inhibition effect of imidazole and its derivatives on mild steel using cluster model. Corros Sci. 2011;53:3086-3091. https://doi.org/10.1016/j.corsci.2011.05.034

46. Olasunkanmi LO, Obot IB, Kabanda MM, et al. Some quinoxalin-6-yl derivatives as corrosion inhibitors for mild steel in hydrochloric acid: experimental and theoretical studies. J Phys Chem. 2015;119:16004-16019. https://doi.org/10.1021/acs.jpcc.5b03285

47. Yesudass S, Olasunkanmi LO, Bahadur I, et al. Experimental and theoretical studies on some selected ionic liquids with different cations/anions as corrosion inhibitors for mild steel in acidic medium. J Taiwan Inst Chem E. 2016;64:252-268. https://doi.org/10.1016/j.jtice.2016.04.006

48. Kumar SH, Karthikeyan S. Torsemide and furosemide as green inhibitors for the corrosion of mild steel in hydrochloric acid medium. Ind Eng Chem Res. 2013;52:7457-7469. https://doi.org/10.1021/ie400815w 
49. Yadav DK, Quraishi MA. Electrochemical investigation of substituted pyranopyrazoles adsorption on mild steel in acid solution. Ind Eng Chem Res. 2012;51:8194-8210. https://doi.org/10.1021/ie3002155

50. de Souza FS, Spinelli A. Caffeic acid as a green corrosion inhibitor for mild steel. Corros Sci. 2009;51:642-649. https://doi.org/10.1016/j.corsci.2008.12.013

51. Mukhopadhyay A, Barman TK, Sahoo P. Corrosion Resistance of Electroless Ni-B-W-Mo Coatings Using Electrochemical Impedance Spectroscopy. Port Electrochim Acta. 2019;37(3):193-203. https://doi.org/10.4152/pea.201903193

52. Yurt A, Balabanb A, Kandemira SU, et al. Investigation on some Schiff bases as $\mathrm{HCl}$ corrosion inhibitors for carbon steel. Mater Chem Phys. 2004;85:420-426. https://doi.org/10.1016/j.matchemphys.2004.01.033

53. Quraishi MA, Singh A, Singh VK, et al. Green approach to corrosion inhibition of mild steel in hydrochloric acid and sulphuric acid solutions by the extract of Murraya koenigii leaves. Mater Chem Phys. 2010;122:114122. https://doi.org/10.1016/j.matchemphys.2010.02.066

54. Morad M, Morvan J, Pagetti J. Proceedings of the eighth European symposium on corrosion inhibitors (8SEIC), Sez V, Suppl. N 10, Annali dell' Università di Ferrara, NS, 1995, p. 159.

55. Mansfeld F. Recording and analysis of AC impedance data for corrosion studies. Corrosion. 1981;37:301-307. https://doi.org/10.5006/1.3621688

56. Quraishi MA, Wajid Khan MA, Ajmal M, et al. Influence of substituted benzothiazoles on corrosion in acid solution. J Appl Electrochem. 1996;26:1253-1258. https://doi.org/10.1007/BF00249927

57. Döner A, Solmaz R, Özcan M, et al. Experimental and theoretical studies of thiazoles as corrosion inhibitors for mild steel in sulphuric acid solution. Corros Sci. 2011;53:2902-2913. https://doi.org/10.1016/j.corsci.2011.05.027

58. Jacob KS, Parameswaran G. Corrosion inhibition of mild steel in hydrochloric acid solution by Schiff base furoin thiosemicarbazone. Corros Sci. 2010;52:224-228. https://doi.org/10.1016/j.corsci.2009.09.007

59. Khadiri A, Saddik R, Bekkouche K, et al. Gravimetric, electrochemical and quantum chemical studies of some pyridazine derivatives as corrosion inhibitors for mild steel in $1 \mathrm{M} \mathrm{HCl}$ solution. J Taiwan Inst Chem E. 2016;58:552-564. https://doi.org/10.1016/j.jtice.2015.06.031

60. Hamani H, Douadi T, Al-Noaimi M, et al. Electrochemical and quantum chemical studies of some azomethine compounds as corrosion inhibitors for mild steel in 1M hydrochloric acid. Corros Sci. 2014;88:234-245. https://doi.org/10.1016/j.corsci.2014.07.044

61. Tan YJ, Bailey S, Kinsella B. An investigation of the formation and destruction of corrosion inhibitor films using electrochemical impedance spectroscopy (EIS). Corros Sci. 1996;38:1545-1561. https://doi.org/10.1016/0010-938X(96)00047-9

62. Popova A, Sokolova E, Raicheva S, et al. AC and DC study of the temperature effect on mild steel corrosion in acid media in the presence of 
benzimidazole derivatives. Corros Sci. 2003;45:33-58. https://doi.org/10.1016/S0010-938X(02)00072-0

63. Srimathi M, Rajalakshmi R, Subhashini S. Polyvinyl alcohol-sulphanilic acid water soluble composite as corrosion inhibitor for mild steel in hydrochloric acid medium. Arab J Chem. 2014;7:647-656. https://doi.org/10.1016/j.arabjc.2010.11.013

64. Bentiss F, Lebrini M, Lagreneé $M$. Thermodynamic characterization of metal dissolution and inhibitor adsorption processes in mild steel/2,5-bis(nthienyl)-1,3,4-thiadiazoles/hydrochloric acid system. Corros Sci. 2005;47: 2915-2931. https://doi.org/10.1016/j.corsci.2005.05.034

65. Lebrini M, Bentiss F, Vezin H, et al. The inhibition of mild steel corrosion in acidic solutions by 2,5-bis(4-pyridyl)-1,3,4-thiadiazole: Structure-activity correlation. Corros Sci. 2006;48:1279-1291. https://doi.org/10.1016/j.corsci.2005.05.001

66. Hegazy MA, El-Tabei AS, Bedair AH, et al. An investigation of three novel nonionic surfactants as corrosion inhibitor for carbon steel in $0.5 \mathrm{M} \mathrm{H}_{2} \mathrm{SO}_{4}$. Corros Sci. 2012;54:219-230. https://doi.org/10.1016/j.corsci.2011.09.019

67. Zhang S, Tao Z, Li W, Hou B. The effect of some triazole derivatives as inhibitors for the corrosion of mild steel in $1 \mathrm{M}$ hydrochloric acid. Appl Surf Sci. 2009;255: 6757-6763. https://doi.org/10.1016/j.apsusc.2008.09.089

68. Hegazy MA, Badawi AM, AbdElRehim SS, et al. Corrosion inhibition of carbon steel using novel N-(2-(2-mercaptoacetoxy)ethyl)-N,Ndimethyldodecan-1-aminiumbromide during acid pickling. Corros Sci. 2013;69:110-122. https://doi.org/10.1016/j.corsci.2012.11.031

69. Wang X, Yang H, Wang F. A cationic Gemini surfactant as effective inhibitor for mild steel in $\mathrm{HCl}$ solutions. Corros Sci. 2010;52:1268-1276. https://doi.org/10.1016/j.corsci.2009.12.018

70. Oguzie EE, Enenebeaku CK, Akalezi CO, et al. Adsorption and corrosion inhibiting effect of Dacryodis edulis extract on low carbon steel corrosion in acidic media. J Colloid Interf Sci. 2010;349:283-292. https://doi.org/10.1016/j.jcis.2010.05.027

71. Torres VV, Amado RS, Faia de Sá C, et al Inhibitory action of aqueous coffee ground extracts on the corrosion of carbon steel in $\mathrm{HCl}$ solution. Corros Sci. 2011;53:2385-2392. https://doi.org/10.1016/j.corsci.2011.03.021

72. Zheng $\mathrm{X}$, Zhang $\mathrm{S}$, Li $\mathrm{W}$, et al. Investigation of 1-butyl-3-methyl-1Hbenzimidazolium iodide as inhibitor for mild steel in sulfuric acid solution. Corros Sci. 2014;80:383-392. https://doi.org/10.1016/j.corsci.2013.11.053

73. Singh AK, Quraishi MA. The effect of some bis-thiadiazole derivatives on the corrosion of mild steel in hydrochloric acid. Corros Sci. 2010;52:13731385. https://doi.org/10.1016/j.corsci.2010.01.007

74. Quraishi MA, Rafiquee MZA, Khan S, et al. Corrosion inhibition of aluminium in acid solutions by some imidazoline derivatives. J Appl Electrochem. 2007;37:1153-62. https://doi.org/10.1007/s10800-007-9379-0

75. AbdEl-Rehim SS, Refaey SAM, Taha F, et al. Corrosion inhibition of mild steel in acidic medium using 2-aminothiophenol and 2-cyano methyl 
benzothiazole. J Appl Electrochem. 2001;31:429-435. https://doi.org/10.1023/A:1017592322277

76. Guan NM, Xueming L, Fei L. Synergistic inhibition between ophenanthroline and chloride ion on cold rolled steel corrosion in phosphoric acid. Mater Chem Phys. 2004;86:59-68. https://doi.org/10.1016/j.matchemphys.2004.01.041

77. Ghames A, Douadi T, Issaadi S, et al. Theoretical and Experimental Studies of Adsorption Characteristics of Newly Synthesized Schiff Bases and their Evaluation as Corrosion Inhibitors for Mild Steel in $1 \mathrm{M} \mathrm{HCl}$. Int $\mathrm{J}$ Electrochem Sci. 2017;12:4867-4897. https://doi.org/10.20964/2017.06.92

78. Benabid S, Douadi T, Issaadi S, et al. Electrochemical and DFT studies of a new synthesized Schiff base as corrosion inhibitor in $1 \mathrm{M} \mathrm{HCl}$. Measurement. 2017;99:53-63. https://doi.org/10.1016/j.measurement.2016.12.022

79. Hamani H, Douadi T, Daoud D, et al. 1-(4-Nitrophenylo-imino)-1(phenylhydrazono)-propan-2-one as corrosion inhibitor for mild steel in $1 \mathrm{M}$ $\mathrm{HCl}$ solution: Weight loss, electrochemical, thermodynamic and quantum chemical studies. J Electroanal Chem. 2017;801:425-438. https://doi.org/10.1016/j.jelechem.2017.08.031

80. Herrag L, Hammouti B, Elkadiri S, et al. Adsorption properties and inhibition of mild steel corrosion in hydrochloric solution by some newly synthesized diamine derivatives: Experimental and theoretical investigations. Corros Sci. 2010;52:3042-3051. https://doi.org/10.1016/j.corsci.2010.05.024

81. Szauer T, Brand A. On the role of fatty acid in adsorption and corrosion inhibition of iron by amine-fatty acid salts in acidic solution. Electrochim Acta. 1981;26:1257-1260. https://doi.org/10.1016/0013-4686(81)85108-0

82. Kumari PP, Rao SA, Shetty P. Corrosion inhibition of mild steel in $2 \mathrm{M} \mathrm{HCl}$ by a Schiff base derivative. Procedia Mater Sci. 2014;5:499-507. https://doi.org/10.1016/j.mspro.2014.07.293

83. Oguzie EE. Evaluation of the inhibitive effect of some plant extracts on the acid corrosion of mild steel. Corros Sci. 2008;50:2993-2998. https://doi.org/10.1016/j.corsci.2008.08.004

84. Bahrami MJ, Hosseini SMA, Pilvar P. Experimental and theoretical investigation of organic compounds as inhibitors for mild steel corrosion in sulfuric acid medium. Corros Sci. 2010;52:2793-2803. https://doi.org/10.1016/j.corsci.2010.04.024

85. Bouklah M, Hammouti B, Lagrenee M, et al. Thermodynamic properties of 2,5-bis(4-methoxyphenyl)-1,3,4-oxadiazole as a corrosion inhibitor for mild steel in normal sulfuric acid medium. Corros Sci. 2006;48:2831-42. https://doi.org/10.1016/j.corsci.2005.08.019

86. Pradeep Kumar CB, Mohana KN. Corrosion inhibition efficiency and adsorption characteristics of some Schiff bases at mild steel/hydrochloric acid interface. J Taiwan Inst Chem E. 2014;45:1031-1042. https://doi.org/10.1016/j.jtice.2013.08.017

87. Guan NM, Xueming L, Fei L. Synergistic inhibition between oophenanthroline and chloride ion on cold rolled steel corrosion in phosphoric 
acid. Mater Chem Phys. 2004;86:59-68. https://doi.org/10.1016/j.matchemphys.2004.01.041

88. Bockris JO, Swinkels DAJ. Adsorption of normal decylamine on solid metal $\begin{array}{llll}\text { electrodes. } & \mathrm{J} & \text { Electrochem } & \text { Soc. }\end{array}$ https://doi.org/10.1149/1.2426222

89. Narváez L, Cano E, Bastidas DM. 3-Hydroxybenzoic acid as AISI 316L stainless steel corrosion inhibitor in a $\mathrm{H}_{2} \mathrm{SO}_{4}-\mathrm{HF}-\mathrm{H}_{2} \mathrm{O}_{2}$ pickling solution. $\mathrm{J}$ Appl Electrochem. 2005;35:499-506. https://doi.org/10.1007/s10800-0050291-1

90. Flores EA, Olivares O, Likhanova NV, et al. Sodium phthalamates as corrosion inhibitors for carbon steel in aqueous hydrochloric acid solution. Corros Sci. 2011;53:3899-3913. https://doi.org/10.1016/j.corsci.2011.07.023

91. Bayol E, Kayakirilmaz K, Erbil M. The inhibitive effect of hexamethylenetetramine on the acid corrosion of steel. Mater Chem Phys. 2007;104:74-82. https://doi.org/10.1016/j.matchemphys.2007.02.073

92. Tang L, Mu G, Liu G. The effect of neutral red on the corrosion inhibition of cold rolled steel in 1.0 M hydrochloric acid. Corros Sci.2003;45:2251-2262. https://doi.org/10.1016/S0010-938X(03)00046-5

93. Cano E, Polo JL, La Iglesia A, et al. A study on the adsorption of benzotriazole on copper in hydrochloric acid using the inflection point of the isotherm. Adsorption. 2004;10:219-225. https://doi.org/10.1023/B:ADSO.0000046358.35572.4c

94. Deng S, Li X, Fu H. Two pyrazine derivatives as inhibitors of the cold rolled steel corrosion in hydrochloric acid solution. Corros Sci. 2011;53: 822-828. https://doi.org/10.1016/j.corsci.2010.11.019

95. Hegazy MA, Ahmed HM, El-Tabei AS. Investigation of the inhibitive effect of p-substituted 4-(N,N,N-dimethyldodecylammonium bromide) benzylidenebenzene-2-yl-amine on corrosion of carbon steel pipelines in acidic medium. Corros Sci. 2011;53:671-678. https://doi.org/10.1016/j.corsci.2010.10.004

96. Badiea AM, Mohana KN. Effect of temperature and fluid velocity on corrosion mechanism of low carbon steel in presence of 2-hydrazino-4,7dimethylbenzothiazole in industrial water medium. Corros Sci. 2009;51:2231-2241. https://doi.org/10.1016/j.corsci.2009.06.011

97. Mourya P, Banerjee S, Singh MM. Inhibition of mild steel corrosion in hydrochloric and sulphuric acid media using a thiosemicarbazone derivative. Ind Eng Chem Res. 2013;52:12733-12747. https://doi.org/10.1021/ie4012497

98. Mourya P, Singh P, Tewari AK, et al. Relationship between structure and inhibition behaviour of quinolinium salts for mild steel corrosion: Experimental and theoretical approach. Corros Sci. 2015;95:71-87. https://doi.org/10.1016/j.corsci.2015.02.034

99. Hameed RSA. Aminolysis of polyethylene terephthalate waste as corrosion inhibitor for carbon steel in $\mathrm{HCl}$ corrosive medium. Adv Appl Sci Res. 2011;2:483-499. 
100. Daoud D, Douadi T, Issaadi S, et al. Adsorption and corrosion inhibition of new synthesized thiophene Schiff base on mild steel X52 in $\mathrm{HCl}$ and $\mathrm{H}_{2} \mathrm{SO}_{4}$ $\begin{array}{llll}\text { solutions. } & \text { Corros } & \text { Sci. } & \text { 2014;79 }\end{array}$ https://doi.org/10.1016/j.corsci.2013.10.025

101. Saha SKr, Murmu M, Murmu NC, et al. Molecular level insights for the corrosion inhibition effectiveness of three amine derivatives on the carbon steel surface in the adverse medium: A combined density functional theory and molecular dynamics simulation study. Surf Interfaces. 2018;10:65-73. https://doi.org/10.1016/j.surfin.2017.11.007

102. Daoud D, Douadi T, Hamani H, et al. Corrosion inhibition of mild steel by two new S-heterocyclic compounds in $1 \mathrm{M} \mathrm{HCl}$ : Experimental and computational study. Corros Sci. 2015;94:21-37. https://doi.org/10.1016/j.corsci.2015.01.025

103. Snehalatha M, Ravikumar C, Hubert Joe I, et al. Spectroscopic analysis and DFT calculations of a food additive Carmoisine. Spectrochim Acta A. 2009;72:654-662. https://doi.org/10.1016/j.saa.2008.11.017

104. Zhou J, Chen S, Zhang L, et al. Studies of protection of self-assembled films by 2-mercapto-5-methyl-1, 3, 4-thiadiazole on iron surface in $0.1 \mathrm{M} \mathrm{H}_{2} \mathrm{SO}_{4}$ solutions. J Electroanal Chem. 2008;612:257-268. https://doi.org/10.1016/j.jelechem.2007.10.011

105. Khaled KF. Molecular simulation, quantum chemical calculations and electrochemical studies for inhibition of carbon steel by triazoles. Electrochim Acta. 2008;53:3484-3492. https://doi.org/10.1016/j.electacta.2007.12.030 